\title{
Novel heterococcolithophores, holococcolithophores and life cycle combinations from the families Syracosphaeraceae and Papposphaeraceae and the genus Florisphaera
}

\author{
Sabine Keuter ${ }^{1,2}$, Jeremy R. Young ${ }^{3}$, Gil Koplovitz ${ }^{1}$, Adriana Zingone ${ }^{4}$, and Miguel J. Frada ${ }^{1,2}$ \\ ${ }^{1}$ The Interuniversity Institute for Marine Sciences in Eilat, POB 469, 88103 Eilat, Israel \\ ${ }^{2}$ Dept. of Ecology, Evolution and Behavior - Alexander Silberman Institute of Life Sciences, \\ Hebrew University of Jerusalem, 91904 Jerusalem, Israel \\ ${ }^{3}$ Department of Earth Sciences, University College London, Gower Street, London WC1E 6BT, UK \\ ${ }^{4}$ Stazione Zoologica Anton Dohrn, Villa Comunale, Naples, Italy \\ Correspondence: Miguel J. Frada (miguel.frada@mail.huji.ac.il) \\ and Jeremy R. Young (jeremy.young@ucl.ac.uk)
}

Received: 14 April 2021 - Revised: 18 June 2021 - Accepted: 22 June 2021 - Published: 18 August 2021

\begin{abstract}
Coccolithophores are a diverse group of calcifying phytoplankton, which are responsible for a large part of the modern oceanic carbonate production. Here, we describe novel or poorly known coccolithophores and novel life cycle combination coccospheres detected in samples collected either in the Gulf of Aqaba in the northern Red Sea or in the Gulf of Naples in the western Mediterranean. These include Syracosphaera winteri, for which detached coccoliths have previously been recorded but both a formal description and taxonomic affiliation were lacking, and five undescribed sets of combination cells linking HET and HOL forms for S. pulchra, S. mediterranea, S. azureaplaneta, S. lamina and S. orbicula. We also propose the replacement name $S$. kareniae for the fossil species Deutschlandia gaarderae. We describe a new species of the genus Ophiaster, O. macrospinus, displaying a unique morphological and ecological distribution as well as putative combination cells of two variants of the deep-dwelling Florisphaera profunda, which provide new insights on the affiliation of this genus within the Calcihaptophycideae. Additionally, in the family Papposphaeraceae we detected a new species, Pappomonas vexillata, and combination cells of Picarola margalefi and of a species resembling Papposphaera arctica. Finally, we detected three novel, unpaired holococcolithophore forms (Calyptrosphaera lluisae, Calicasphaera bipora and one form designated as Holococcolithophore A). Overall, this set of novel observations and ensuing discussions provide further insights into the diversity, evolution and life cycle complexity of coccolithophores in the oceans.
\end{abstract}

\section{Introduction}

Coccolithophores (class Prymnesiophyceae, subclass Calcihaptophycidae) are calcifying protists that characteristically produce an exoskeleton (the coccosphere) made of multiple calcium carbonate scales called coccoliths (Young et al., 1999). Coccolithophores are a major component of phytoplankton communities in the oceans and significant contributors to marine primary productivity (e.g., Okada and McIn- tyre, 1979; Poulton et al., 2017). Additionally, due to calcification, coccolithophores influence seawater alkalinity and act as ballast in faecal pellets of zooplankton and in marine aggregates, thus enhancing the export of biogenic matter to the deep ocean and sediments (e.g., Milliman, 1993; Poulton et al., 2007; Ziveri et al., 2007; Broecker and Clark, 2009). Long-term deposition of coccoliths in marine sediments has created a remarkably successive fossil record across both the Mesozoic and Cenozoic that is widely used in biostratigra- 
phy and paleoceanography (e.g., Bown et al., 2004). Coccolithophores also intracellularly produce a high amount of dimethylsulfoniopropionate (DMSP) that is the precursor of the volatile gas dimethylsulfide (DMS), which can act as condensation nuclei that increase cloud albedo and thus impact climate (Charlson et al., 1987; Franklin et al., 2010).

A core attribute of coccolithophores is their life cycle. Most species can appear as either of two morphologically distinct life stages that have different ploidy levels, one being haploid and the other diploid (haplodiplontic life cycle). Typically, diploid cells produce heterococcoliths that are composed of a complex radial array of interlocked calcite crystals. In contrast, in certain core groups of coccolithophores, the haploid cells produce holococcoliths formed of assemblies of euhedral calcite crystallites. These two life cycle phases with coccoliths are usually denominated as heterococcolithophore (HET) and holococcolithophore (HOL), respectively. In other species, however, the haploid cells produce "nannoliths" without the features of either hetero- or holococcoliths, or they lack coccoliths (non-calcified), such as in the family Noelaerhabdaceae that includes the genera Emiliania and Gephyrocapsa, which often numerically dominate coccolithophore assemblages (Billard, 1994; Houdan et al., 2004; Frada et al., 2019). Little is known about the significance of life cycle transitions and the mechanisms driving them. Yet, life cycling may allow coccolithophores to respond and adapt to a broader range of environmental conditions, with each phase performing best in different settings (Houdan et al., 2004; Frada et al., 2019). An important source of evidence for the ability of coccolithophores to undergo life cycle transitions comes from observations of "combination coccospheres" (e.g., Cros et al., 2000; Triantaphyllou et al., 2016). These forms bearing both heteroand holococcoliths are interpreted as cells undergoing transitions between haploid and diploid phases and have therefore enabled the linking of morphologically distinct life phases, thus advancing our understanding of coccolithophore biology, ecology and evolution. Noticeably, in several species the heterococcolithophore life stage can be associated with multiple distinguishable holococcolithophore morphotypes. This has been interpreted either as evidence for intraspecific variation or cryptic speciation only perceptible in the holococcolithophore life phase (Geisen et al., 2002).

We have recently undertaken an intensive study of coccolithophores in the Gulf of Aqaba, in the northeastern end of the Red Sea, to determine their local diversity, ecology and seasonal succession. During that study we encountered several undescribed morphotypes and also combination coccospheres, allowing us to infer novel life cycle associations. These taxonomic observations from the Gulf of Aqaba are supplemented by observations from a second seasonal study of coccolithophores in the Gulf of Naples in the western Mediterranean and from archived images.

\section{Study sites}

The Gulf of Aqaba (GoA) is a deep terminal basin connected at its southern end to the northern Red Sea. Over springsummer the water column is warm (up to $\sim 28^{\circ} \mathrm{C}$ ), markedly stratified and nutrient-limited (considered co-limited for nitrogen and phosphorus; Mackey et al., 2009). Cyanobacteria largely dominate such conditions. However, surface cooling during winter and the presence of a weak temperature gradient across the water column (deepwater temperature is ca. $20.6{ }^{\circ} \mathrm{C}$ ) drive a unique deep vertical mixing. Mixing entrains nutrients to the photic layer, enabling a progressive increment in spring phytoplankton biomass, with blooms of a magnitude that is unusual for subtropical, oligotrophic seas (e.g., Genin et al., 1995; Lindell and Post, 1995; Zarubin et al., 2017).

The Gulf of Naples (GoN) is a temperate coastal embayment adjacent to the city of Naples (Italy) that is influenced both by offshore oligotrophic waters of the Tyrrhenian Sea (western Mediterranean Sea) and eutrophic coastal waters enriched by land runoff (Carrada et al., 1980; Ribera d'Alcalà et al., 2004). The location and width of the boundary between offshore oligotrophic and coastal eutrophic waters are highly dynamic and variable over seasons, entailing exchanges between the two water masses (Cianelli et al., 2017). Typically, the annual cycle is driven by temperature. From December to March the water column is thoroughly mixed and temperatures can be as low as $13.2^{\circ} \mathrm{C}$. From mid-March a temperature increase (up to $28.9^{\circ} \mathrm{C}$ in late July) drives the water column towards stratification. The nutrient decrease over late spring-summer is interrupted by an influx of nutrients through municipal runoff (Ribera d'Alcalà et al., 2004). In surface waters, phytoplankton biomass, typically dominated by diatoms and phytoflagellates most of the year, may increase from late winter and generally reaches a maximum in late spring, with frequent additional peaks over the summer and a less conspicuous autumn bloom (Zingone et al., 2010, 2019).

\section{Materials and methods}

Seawater samples from the GoA were collected using Niskin bottles through the photic layer $(0-140 \mathrm{~m})$ between March 2017 and December 2018 at Station A $\left(29.467^{\circ}\right.$ N, $34.929^{\circ} \mathrm{E}$ ), an offshore $750 \mathrm{~m}$ deep station regularly monitored for oceanographic parameters by the Interuniversity Institute for Marine Sciences in Eilat (IUI) (see Zarubin et al., 2017). Samples from the GoN were collected with Niskin bottles through the water column $(0-60 \mathrm{~m})$ between June 2016 and July 2017 in the framework of the LongTerm Ecological Research program conducted at the site MareChiara (LTER-MC; $40.816^{\circ} \mathrm{N}, 14.25^{\circ} \mathrm{E}$ ) (see Zingone et al., 2019). Details of the samples used in this study can be found in Table S1 in the Supplement. Observations were also made on samples collected during onshore incubations 
of seawater from the GoA. For the latter, seawater from Station A ( $20 \mathrm{~m}$, in summer) or surface water collected near the shore (November) was gently transferred into $10 \mathrm{~L}$ transparent containers and kept for 2-5 d at in situ temperature and light, without or with the addition of nutrients $(1.5 \mu \mathrm{M}$ nitrate and $0.1 \mu \mathrm{M}$ phosphate).

Following pre-screening through a $200 \mu \mathrm{m}$ mesh to remove larger organisms, all samples were filtered onto cellulose nitrate membranes (Whatman; $0.8 \mu \mathrm{m}$ pore size, $47 \mathrm{~mm}$ diameter), rinsed with $\mathrm{NaOH}$-buffered water $(\mathrm{pH} 8.5)$ to remove sea salt and dried. Representative filter portions were mounted on aluminum stubs, sputter-coated with goldpalladium $(\sim 20 \mathrm{~nm})$ and quantitatively screened for coccolithophores using a scanning electron microscope (SEM; Phenom Pro benchtop and JEOL 6700) as described in Keuter et al. (2019). Abundances of species were calculated as $C \times(F / A) / V$, where $C$ is the total number of coccospheres counted, $F$ is the total filter area $\left(\mathrm{mm}^{2}\right), A$ is the area investigated $\left(\mathrm{mm}^{2}\right.$, sum of fields of view inspected) and $V$ is the volume filtered $(\mathrm{mL})$. Cell count data are available in Table S1. High-resolution imaging of selected coccolithophore specimens was performed on a Magellan 400L SEM. In addition, images from our research collections spanning a range of previous studies were used where relevant; details of these are given in the figure captions. For visualization of chloroplasts in cells, freshly filtered material was inspected on a Nikon Eclipse Ti-S fluorescence microscope with $488 \mathrm{~nm}$ excitation and $630 \mathrm{~nm}$ emission wavelengths.

Morphological descriptions followed the terminology of Young et al. (1997), with some modifications suggested by Kleijne and Cros (2009) for Syracosphaeraceae and Andruleit and Young (2010) for Papposphaeraceae. Taxonomical revisions followed the principle of priority as determined by the International Code of Nomenclature for algae, fungi and plants (Turland et al., 2018). When two life cycle phases had been described as separate species, they were treated as synonyms using the name having priority and, where necessary, adding the informal qualifier HET or HOL to indicate the life cycle stage, as discussed by Thomsen et al. (1991), Cros et al. (2000) and Young et al. (2003). In complex cases, e.g., in which two or more holococcolith morphotypes are consistently associated with a single heterococcolith phase, then an additional informal descriptor is added - e.g., Syracosphaera pulchra HOL oblonga type.

The type material of the species described in this study is deposited in the herbarium of the Hebrew University of Jerusalem (HUJ).

\section{Results and discussion}

\subsection{Novelties in the genus Syracosphaera}

Syracosphaera winteri, Keuter, Koplovitz, Zingone, Young and Frada, sp. nov.

Figs. 1 and 2
Syracosphaera sp. A Winter et al. 1979 pl. IV fig. 9

?Syracosphaera histrica Agbali 2014 pl. 7 fig. 7 (the question mark was used by Agbali, 2014, who tentatively identified this specimen of $S$. winteri as $S$. histrica)

Syracosphaera sp. Jordan 1988 pl. 9a-b, pl. 10a

Syracosphaera sp. imaged on the EMIDAS website (http:// www.emidas.org, last access: 22 July 2021) - seven images showing three collapsed coccospheres.

\section{Diagnosis}

Coccosphere dithecate, ca. $20 \mu \mathrm{m}$ diameter, with varimorphic body coccoliths, spine-bearing circum-flagellar coccoliths (CFCs) and an exotheca of coccoliths in the shape of truncated elliptical cones. The exothecal coccoliths are formed of an elliptical imbricate rim, a conical lath cycle of long, delicate elements and a solid central disk. The endothecal coccoliths are both elliptical muroliths with narrow flaring wall and single basal flange. The body coccoliths (BCs) vary from smaller (ca. $2.5 \mu \mathrm{m}$ ) spineless coccoliths away from the flagellar pole to larger coccoliths (ca. $3.5 \mu \mathrm{m}$ ) with moderate spines (up to $1.5 \mu \mathrm{m}$ ). The CFCs are similar to the largest body coccoliths but have longer spines (up to $4.5 \mu \mathrm{m}$ ) with more complex construction.

\section{Material observed}

We examined a total of 9 partial coccospheres together with 10 additional isolated exothecal coccoliths (XCs) (Figs. 1 and 2). Other specimens have been imaged to our knowledge (notably by Alexandra Zeltner from the University of Tübingen, from the Indian Ocean), but these images are currently unavailable.

\section{Holotype}

A specimen (Fig. 1b) collected from Station A, GoA, on 17 August 2017 at a depth of $80 \mathrm{~m}$ and deposited in the herbarium of the Hebrew University, Jerusalem, with the reference number HUJAL/805000.

\section{Etymology}

The name winteri is in honor of Prof. Amos Winter, who first published an image of this species (Winter et al., 1979) and who has been a stimulating colleague over many years.

\section{Coccospheres}

The observed coccospheres are all collapsed and probably incomplete (Fig. 1a-c). The scatters are ca. 20-30 $\mu \mathrm{m}$ across, and an intact coccosphere would probably be about $20 \mu \mathrm{m}$ across and either equant or slightly elongated. The exothecal coccoliths form a complete cover and are arranged opening 


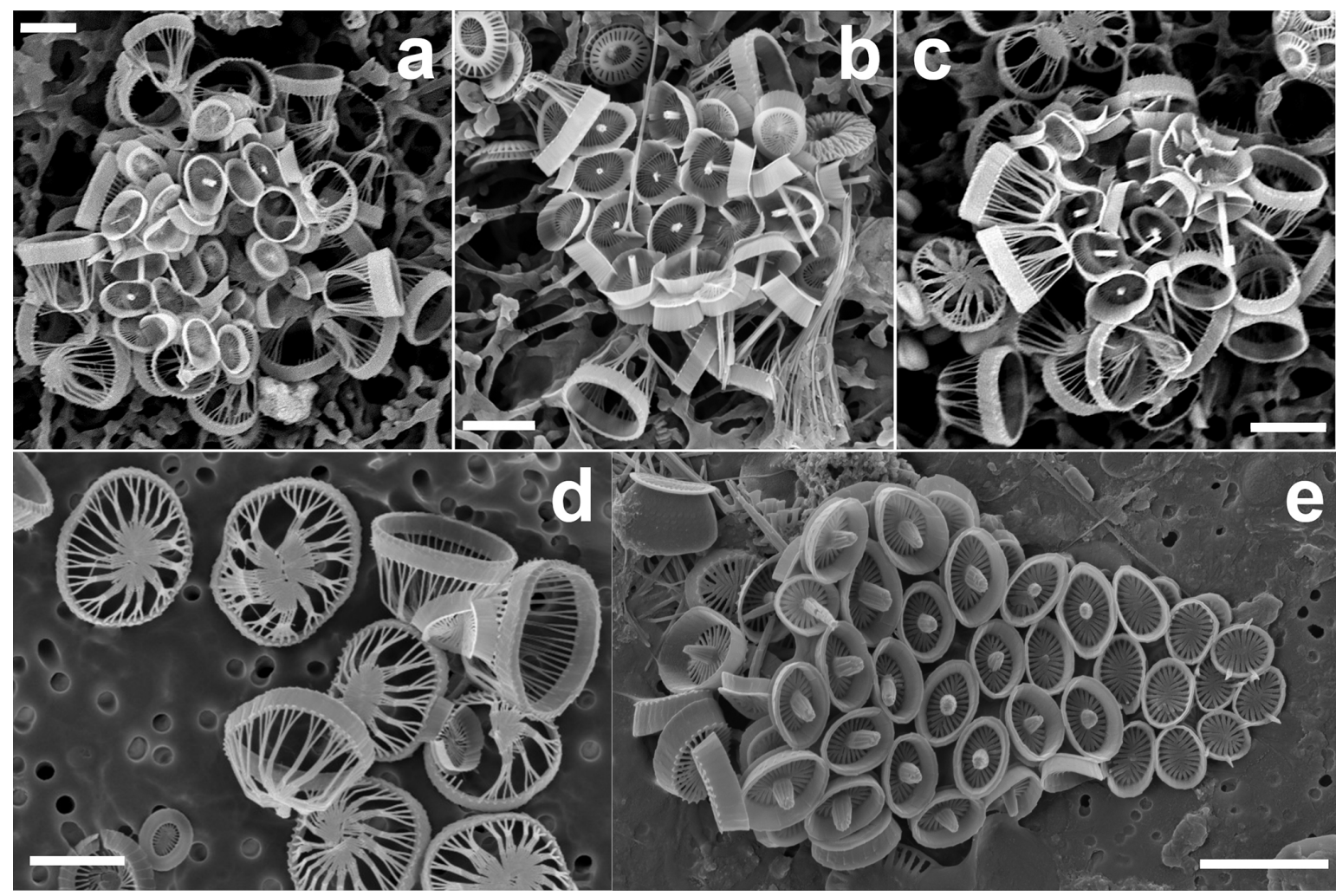

Figure 1. (a-c) Complete coccospheres of Syracosphaera winteri sp.nov., displaying endothecal coccoliths and basket-like exothecal coccoliths. The endothecal coccoliths are muroliths, which appear with or without central processes perpendicular to the coccolith plane (a: GoA, 13 September 2017, 80 m; b and c: GoA, 17 August 2017, 80 m). (d) Series of free basket-like-shaped exothecal coccoliths of $S$. winteri (Tsagaraki, NE Atlantic, $50 \mathrm{~m}$ ); (e) for comparative purposes, coccosphere of Syracosphaera noroitica displaying endothecal coccoliths similar to those of $S$. winteri (Mater II Stn 69/11, October 1999, $50 \mathrm{~m}$ ). Scale bars: $3 \mu \mathrm{m}$. Panel (d) is courtesy of Tatiana Tsagaraki, Bergen University.

outwards; in this orientation their conical shape would allow them to fit together neatly. The endotheca is formed of muroliths which vary in both size and spine development. A few large (ca. $3.5 \mu \mathrm{m}$ ) circum-flagellar coccoliths with long $(3.5-4.5 \mu \mathrm{m})$ spines appear to occur at the flagellar pole. They are surrounded by similar-sized body coccoliths with shorter spines, whilst smaller body coccoliths without spines occur towards the antapical pole of the cell. The variation in coccolith size and spine development in the body coccoliths is gradational.

\section{Body coccoliths}

These are elliptical muroliths, $2.5-3.5 \mu \mathrm{m}$ long. The wall is relatively high $(0.6-0.8 \mu \mathrm{m})$, narrow and flaring (Fig. 2a), with a smooth distal margin and a prominent proximal flange. It is formed of a single cycle of subvertical elements which show minimal overlap or interlocking. The central area is floored by a delicate radial lath cycle, with or without a spine but with no other axial structure. Each lath is formed of two subparts with a slight offset between them, giving the laths a weak laevogyral curvature. The laths extend a short distance up the inner side of the wall. Spines when present range in height from 0.5 to $2.1 \mu \mathrm{m}$. They are parallel-sided and appear to be formed of six to eight rod-like elements, resulting in a star-shaped cross section. The apex of the spine is bluntly truncated and has a central opening.

\section{Circum-flagellar coccoliths}

Similar to the body coccoliths but with long spines (3.3$4.6 \mu \mathrm{m})$. These spines have pointed tips, without a central opening, and are formed of numerous short elements (Fig. 2c).

\section{Exothecal coccoliths}

These are a uniquely distinctive feature of the species. They are basket-like in appearance; in plan view they are elliptical (3.5-5.5 $\mu \mathrm{m}$ long) and in side view cone-shaped (3-4 $\mu \mathrm{m}$ high) with an open outer end and a flat truncated solid base. The rim of the coccolith is a rather robust structure ca. $1 \mu \mathrm{m}$ high $\times 0.2 \mu \mathrm{m}$ wide. The lower part of the rim flares slightly, and the upper part tapers inward to form a lip around the top 

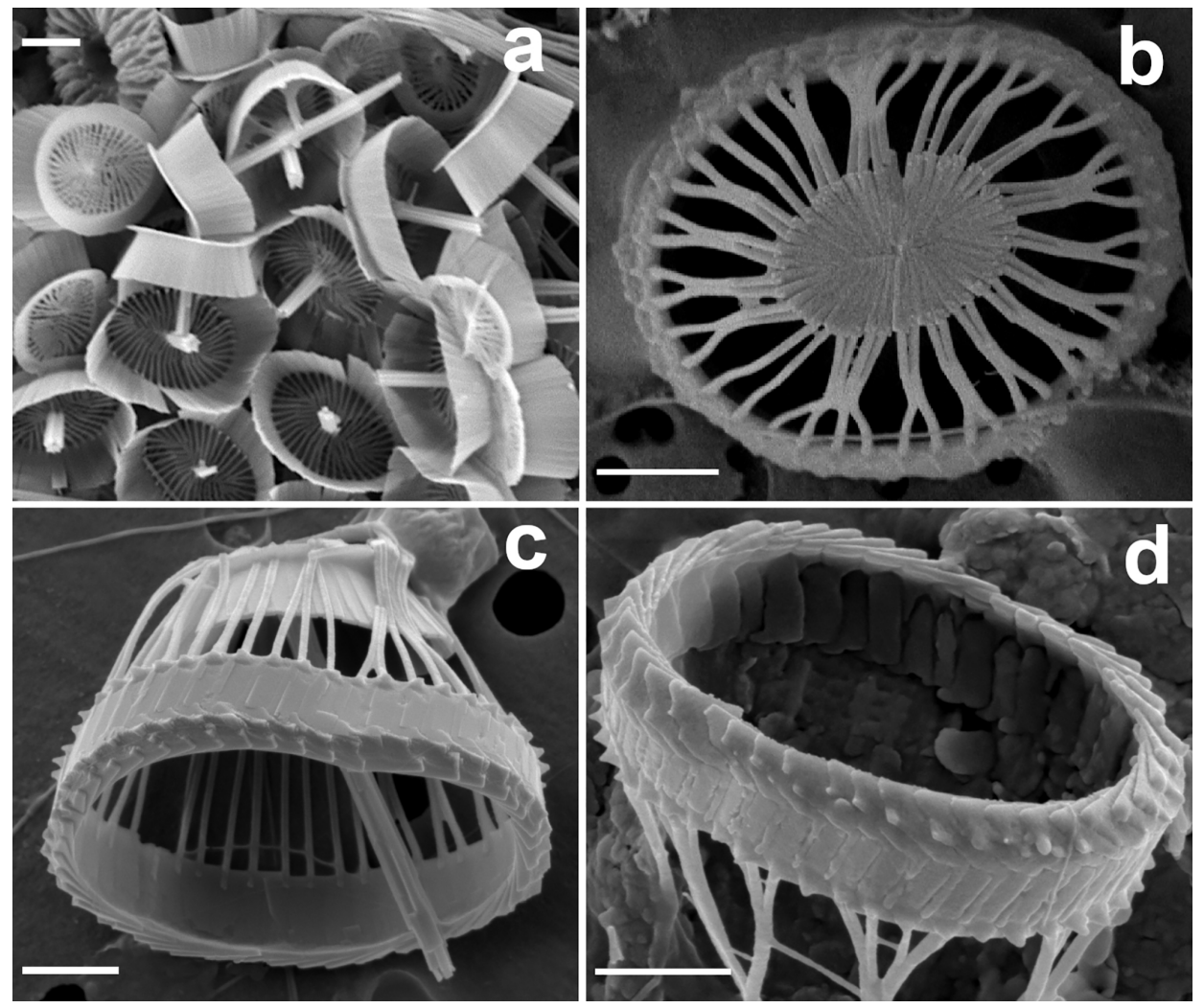

Figure 2. Details of coccoliths of Syracosphaera winteri. (a) Endothecal body coccoliths with short central processes and circum-flagellar coccoliths with longer ones extending perpendicular to the coccolith plane (GoA, 17 August 2017, 80 m). (b) Distal view of exothecal coccoliths showing the central area and arrangement of laths (Mater II Stn 69/11, October 1999, 42.5 m). (c) A circum-flagellar coccolith appears inside an exothecal coccolith, likely an artifact of sampling (AMT18 CTD089, 2 November 2008, 72 m). (d) Slightly etched external coccolith specimen showing clockwise and anticlockwise imbrications of the rim (AMT14 CTD26, 8 May 2004, 120 m). Scale bars: $1 \mu$ m.

of the coccolith. In the flaring part of the rim the elements show anticlockwise imbrication; in the upper tapering part they show clockwise imbrication and strong dextral obliquity. A row of nodes occurs around the base of the rim. A slightly etched specimen (Fig. 2d) suggests that the rim is formed of two cycles of elements, but more observations are needed to determine the full structure.

The main part of the coccolith is formed of radial laths, which are elongate (up to $2 \mu \mathrm{m}$ ) but narrow $(<0.1 \mu \mathrm{m}$ ). There is one lath for each rim element and they meet the rim adjacent to the nodes; on the inner surface they extend up the rim for $0.1-0.2 \mu \mathrm{m}$. At the rim the laths are well separated and a few of them run directly to the central plate. More commonly adjacent laths curve together to meet about half way down from the rim, then continue as composite structures formed of two to five laths. Toward the base of the coccolith the laths are deflected inward toward the central plate but still appear to consist of the same crystal units.

The central plate is typically a solid, flat, elliptical structure ca. $2 \times 1.5 \mu \mathrm{m}$ (Figs. 1d, 2b). It is formed of radiating elements without obvious chirality or imbrication, and each radiating element originates from a single element of the main lath cycle. In other specimens (Fig. 1d), the central plate is less complete and the continuity of the elements with the lath cycle is more obvious, which is similar to the structure of the central area in S. pulchra exothecal coccoliths (Young et al., 2004).

\section{Distribution}

Specimens observed come from the Red Sea, the Mediterranean, the North and South Atlantic Gulf of Mexico, and the Pacific and from $37^{\circ} \mathrm{N}$ (in the western Mediterranean) to $32^{\circ} \mathrm{S}$ (in the South Atlantic), suggesting that, despite its rarity, the species has a global distribution at subtropical and tropical latitudes. All specimens were collected from broadly oligotrophic sites with water depths varying from 12 to $170 \mathrm{~m}$. Mostly the coccospheres were collected from the surface mixed layer, whilst isolated exothecal coccoliths were also observed from deeper water, and the coccosphere specimen of Winter et al. (1979) was collected from $150 \mathrm{~m}$. Water temperatures for the samples varied between $17^{\circ} \mathrm{C}$ and $24.5^{\circ} \mathrm{C}$ 


\section{Affinities}

Only one other Syracosphaera species, S. rotula, forms conical exothecal coccoliths, but these are very different in both overall form and detailed structure, while the body coccoliths considerably vary between the two species. A closer comparison appears to be possible with $S$. noroitica, which has obviously similar body coccoliths but very different exothecal coccoliths. Syracosphaera noroitica is one of a set of rather rare Syracosphaera species characterized by a varimorphic endotheca formed of muroliths with a single proximal flange and by exothecal muroliths typically only weakly differentiated from the body coccoliths. Other species included in the $S$. noroitica group are $S$. castellata and S. florida, which are differentiated for wall height and spine form (Kleijne and Cros, 2009; Nannotax website). A good specimen of $S$. noroitica is shown in Fig. 1e. As noted above, the body coccoliths are almost identical to those of $S$. winteri even in minor details, such as the laths being formed of two subparts extending up the inner wall. The exothecal coccoliths are simple muroliths, with rims similar to those of $S$. winteri $\mathrm{XCs}$, including showing anticlockwise imbrication of the wall elements and a basal ring of nodes. Differently from $S$. winteri $\mathrm{XCs}$, the lath cycle is a flat structure, but it only needs to be grown downward from the rim to develop a similar form.

Syracosphaera kareniae Perch-Nielsen 1980 ex Young, nom. nov. et comb. nov.

Fig. 3

Perch-Nielsen (1980) described the species Deutschlandia gaarderae based on isolated coccoliths from the midPliocene. She placed the species in Deutschlandia on the grounds that the observed coccoliths were very similar to the exothecal coccoliths of D. anthos. She regarded it as a discrete species since the Pliocene coccoliths were larger than those of the modern species $(6-7 \mu \mathrm{m}$ vs. $3.5-5 \mu \mathrm{m})$ and had a taller central cone (height $1.5-2 \times$ width vs. height $<0.5 \times$ width). Whereas this separation still appears justified, Deutschlandia is now regarded as a junior synonym of Syracosphaera, so D. gaarderae should be recombined into Syracosphaera. A further complication is that the name Syracosphaera gaarderae is preoccupied by the species Syracosphaera gaarderae (Borsetti and Cati, 1976) Keuter, Young \& Frada 2019. So, both a new combination and a substitute name are needed for this taxon. We propose the name Syracosphaera kareniae (Perch-Nielsen).

\section{Replaced basionym}

Deutschlandia gaarderae Perch-Nielsen (Eclogae Geologae Helvetiae, 73: 1980, pp. 1-2, pl. 1 figs. 1-10, 16).

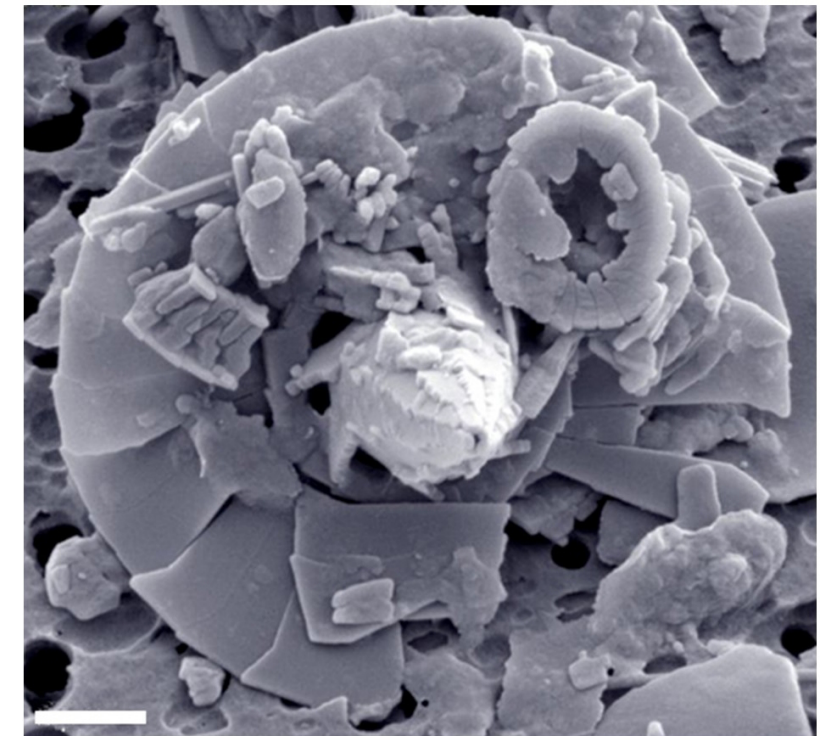

Figure 3. Fossil exothecal coccolith of Syracosphaera kareniae, ODP 1000A-16H-1, $55 \mathrm{~cm}$. Scale bar: $1 \mu \mathrm{m}$.

\section{Etymology}

The name kareniae is based on the first name of Karen Ringdal Gaarder, the distinguished phycologist who was honored in the choice of the original name.

\subsection{New combination coccospheres involving species of the genus Syracosphaera}

Syracosphaera pulchra Lohmann 1902 HOL galea type

Figs. 4 and 5

Calyptrosphaera galea Norris 1985 fig. 27

Calyptrosphaera oblonga Lohmann 1902 - Winter et al. 1979 pl. 4 fig. 11

Calyptrosphaera dentata Kleijne 1991 - Yang et al. 2001 plate1 figs. 2-3

The species Syracosphaera pulchra was described based on its heterococcolith-producing stage and is a common, widespread and well-known coccolithophore. It has since been shown to have an alternate life cycle stage which produces holococcoliths, but with the complication that coccospheres with two different holococcolith types can occur. Previously known as separate species, Calyptrosphaera oblonga and Calyptrosphaera pirus (Daktylethra pirus) are now identified as Syracosphaera pulchra HOL oblonga type and Syracosphaera pulchra HOL pirus type. Yet, it has not been clarified if these represent separate species that only show morphological differentiation in the holococcolith phase or if they are intraspecific variants (see discussion in Geisen et al., 2002). 


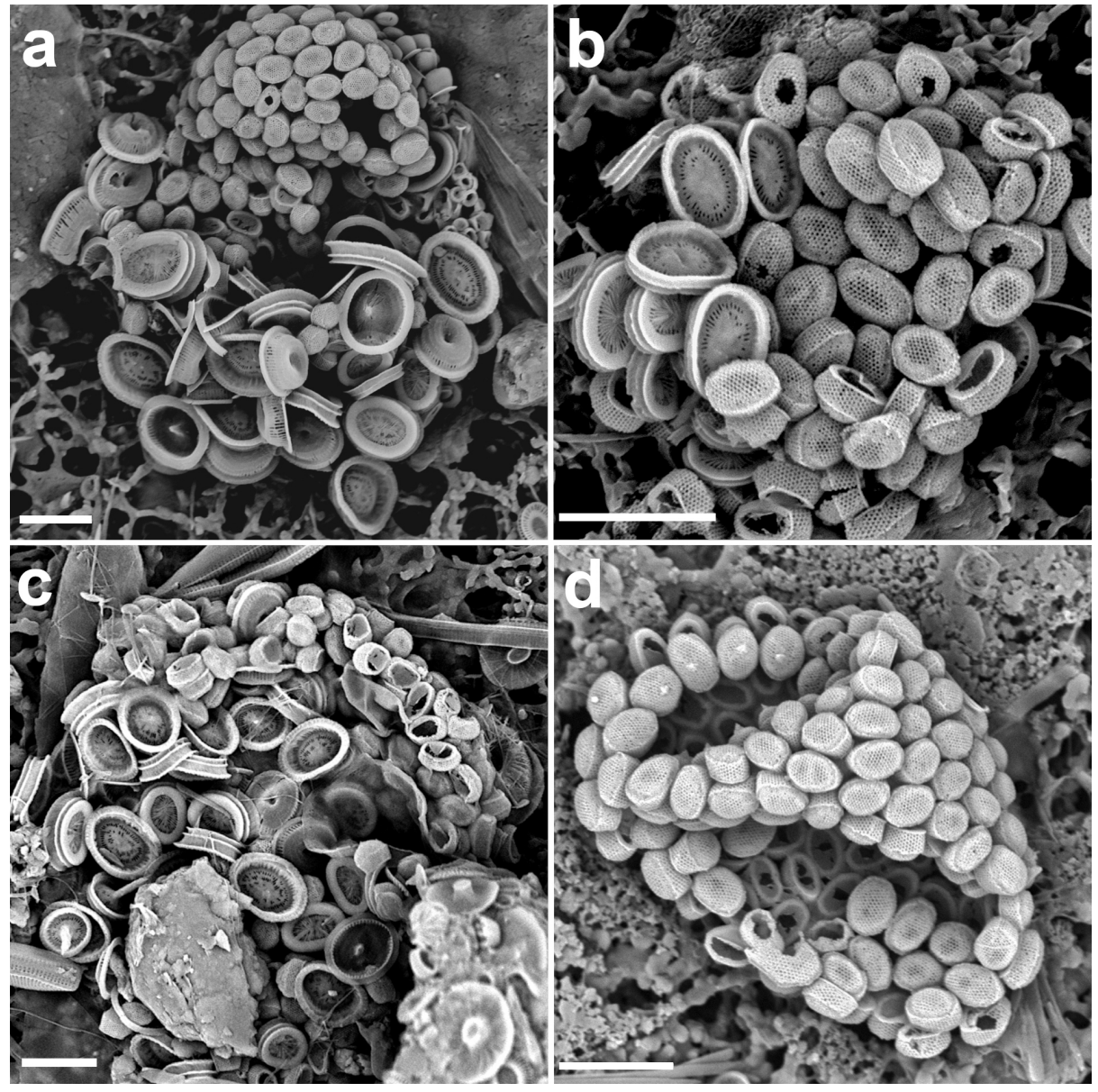

Figure 4. (a-c) Life cycle combination cells of Syracosphaera pulchra in the GoA with the holococcoliths of the galea type (a: 11 July 2017 , 40 m; b: 18 June 2018, 20 m; c: 18 October 2017, 10 m). (d) Complete holococcolithophore cell of S. pulchra HOL galea type (28 May 2017, $20 \mathrm{~m}$ ). Circum-flagellar coccoliths bearing pyramidal bosses can be detected in the upper side of the cell. Scale bars: $5 \mu \mathrm{m}$.

In the GoA we observed 10 combination coccospheres of S. pulchra heterococcoliths and holococcoliths, with the latter being different from both the pirus and oblonga holococcolith types (Figs. 4, 5a, b). These combination cells appeared in the upper photic layers during the spring-summer when the water column is stratified. Over the same period, we also found complete coccospheres with these holococcoliths (Figs. 4d, 6a). These holococcoliths are similar to the oblonga type in having hexagonal meshwork crystallite arrangement and lacking large perforations, but they show a sharp separation of the tube and distal cover like in the pirus type. As in the pirus and oblonga types, the CFCs are differentiated by bearing a pyramidal boss. Thus, these holococcoliths appear to be intermediate between the oblonga and pirus types (Fig. 5). Examination of the literature and archive images revealed several more specimens of this holococcolith morphotype, described as Calyptrosphaera galea (LecalSchlauder 1951) Norris 1985 . The specimens illustrated by Norris (1985) show a finely perforate band about three crystallites high at the top of the tube, which is lacking on the specimens of our combination coccospheres (Fig. 5c). However, similar variation is shown by pirus-type holococcoliths (Fig. 5e, f), and the presence or absence of this feature is not entirely consistent on single coccospheres. So, we do not consider it useful to discriminate the holococcoliths in the specimens from the GoA from the galea-type holococcoliths.

\section{Systematics}

C. galea holococcoliths are intermediate in form between those of $S$. pulchra HOL pirus type and $S$. pulchra $\mathrm{HOL}$ oblonga type, and they occur on combination coccospheres with S. pulchra heterococcoliths. Hence, they should not be regarded as a separate species but a third holococcolith morphotype of S. pulchra. Thus, the species name Calytrosphaera galea is a junior synonym of $S$. pulchra, but the holococcolith morphology can be informally designated as S. pulchra HOL galea type. 

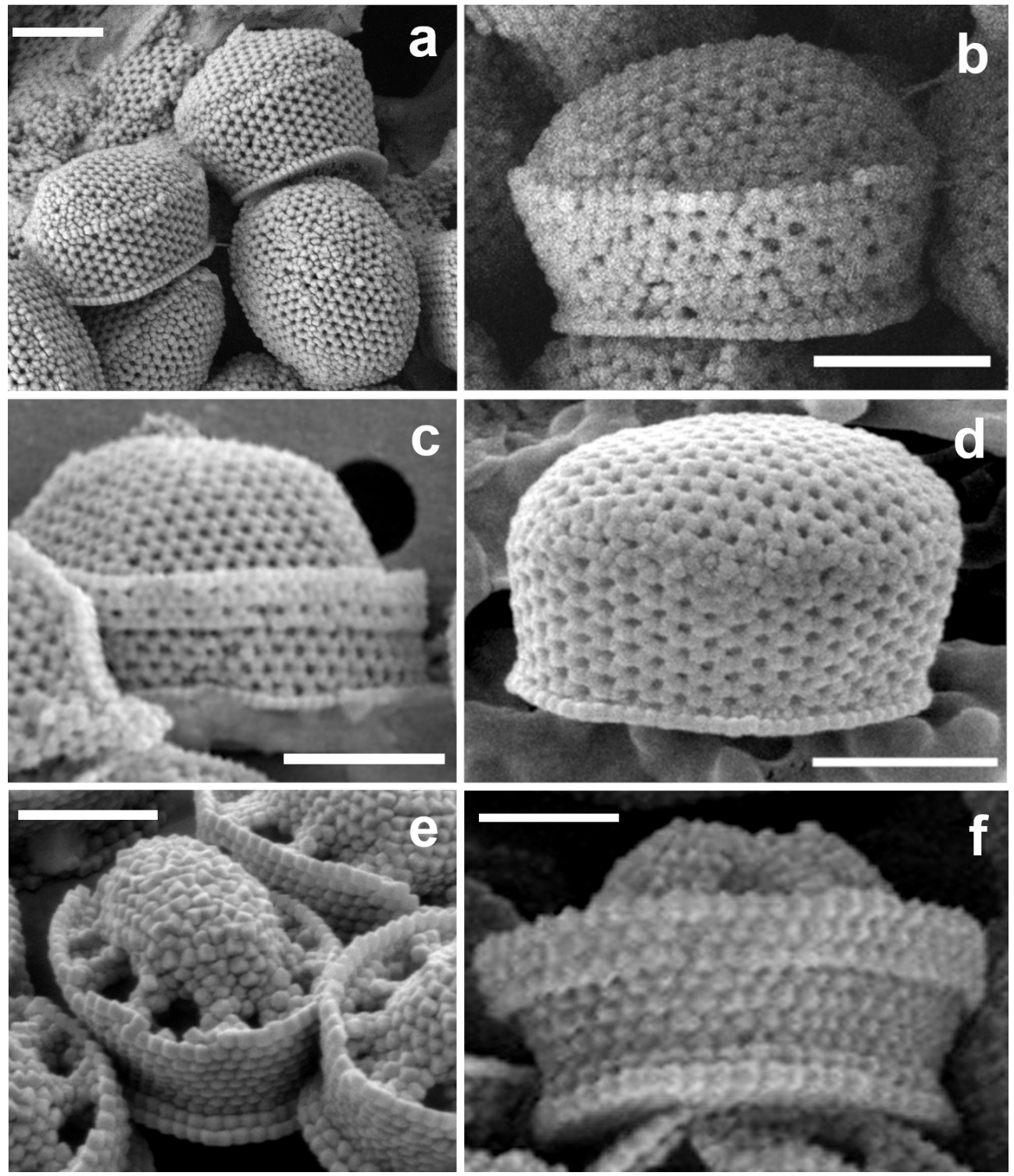

Figure 5. Close-ups of the four holococcolith types associated with Syracosphaera pulchra. (a-c) Galea-type variants (a, b) found in the GoA (17 August 2017, $40 \mathrm{~m}$ ) have a single-crystallite band separating the upper dome from the side walls, whereas (c) the typical galea variant shows a more pronounced band formed of three crystallites (AMT18 CTD089, 2 November 2008, 0 m). (d) Oblonga type without a clear separation between the tube and cover (M38/1 Stn13, 29 January 1997, 5 m). (e) Pirus type without and (f) with a band about three crystallites high at the top of the tube (HOTS169 Stn2, June 2004, 80 m, and MATER II Stn69/12, October 1999, 35 m). Scale bars: $1 \mu$ m.

\section{Discussion}

These observations increase the range of holococcolith morphotypes formed by $S$. pulchra but diminish the separation between them. This is arguably evidence for the differentiation being intraspecific rather than interspecific, yet confirmation of this is still lacking.

Syracosphaera mediterranea Lohmann 1902

HOL marisrubri type

Fig. 7
The heterococcolithophore $S$. mediterranea (Coronosphaera mediterranea) is commonly found in temperate to tropical waters. Three distinct alternate life cycle stages bearing holococcoliths have been recognized; $S$. mediterranea HOL wettsteinii type, S. mediterranea HOL gracillima type and $S$. mediterranea HOL hellenica type. These were each previously regarded as a discrete species (Calyptrolithina wettsteinii, Calyptrolithophora gracillima and Zygosphaera hellenica), but the associations have each been verified by multiple observations of combination coccospheres (Cortés and Bollmann, 2002; Cros et al., 2000; 
(a)

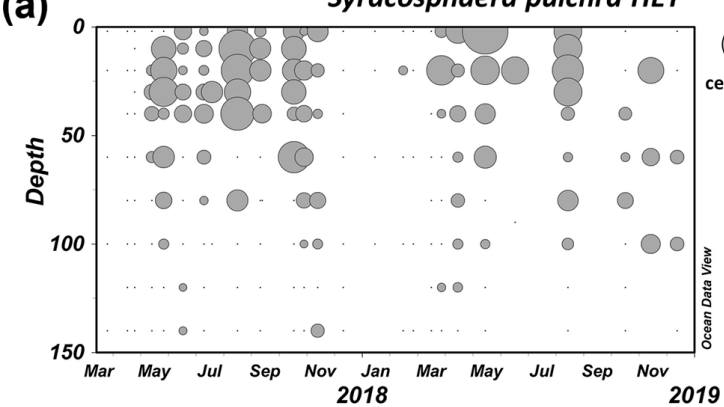

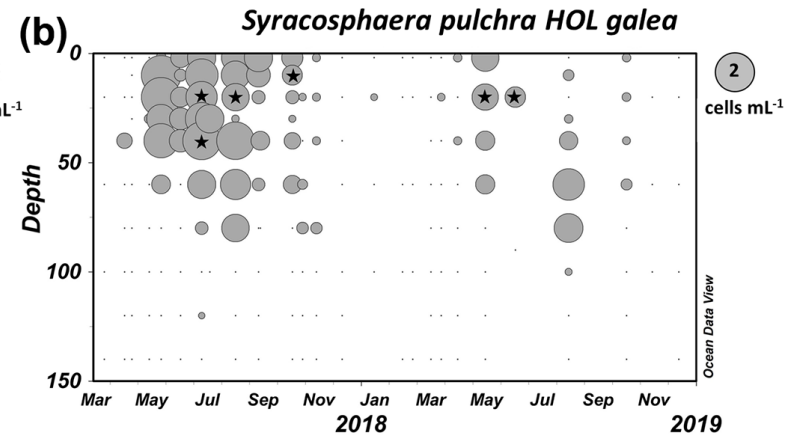

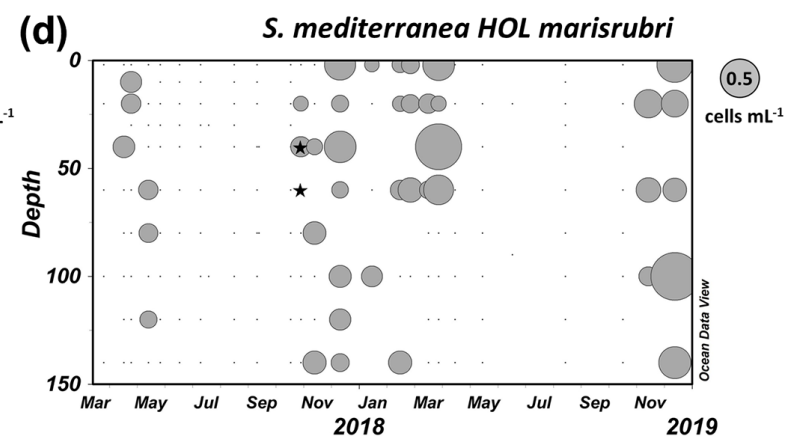

(c)

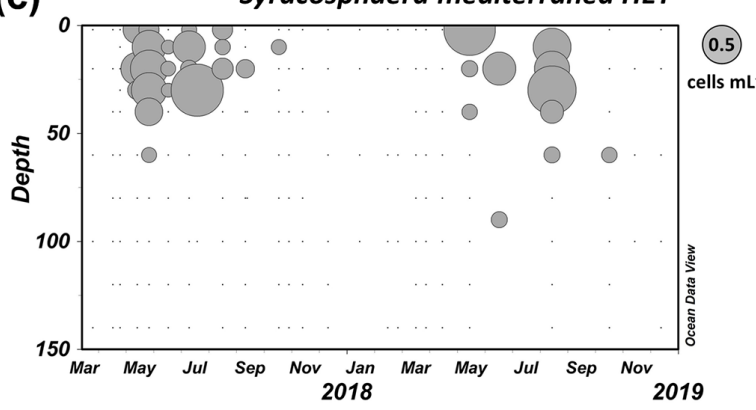

Syracosphaera mediterranea HET (e)

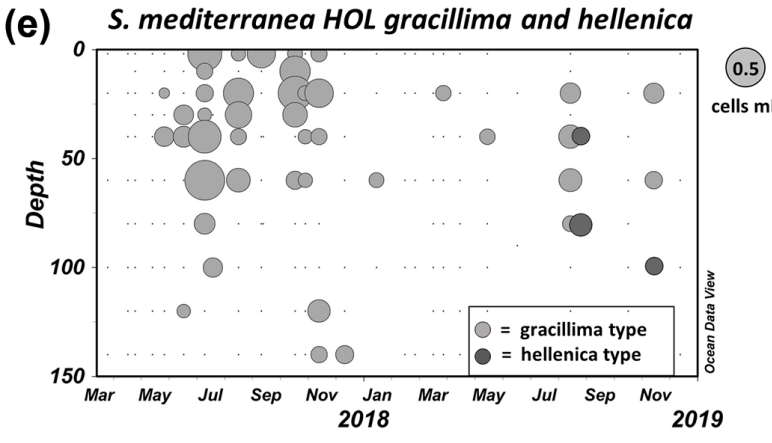

(f)

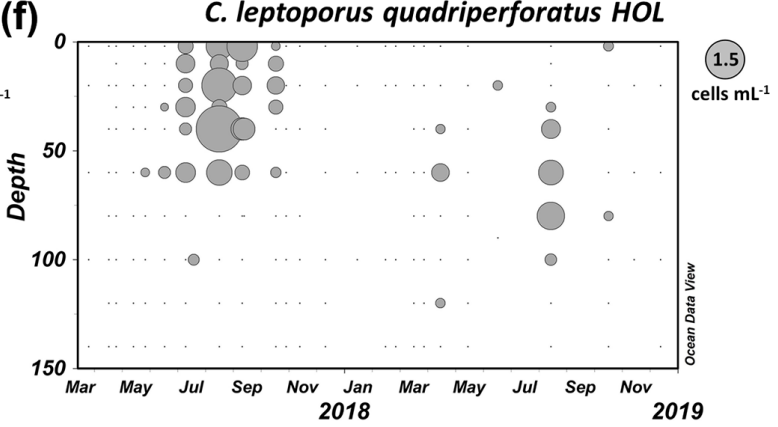

Figure 6. Distribution of coccolithophores in the GoA between March 2017 and December 2018. (a, b) Syracosphaera pulchra HET and Syracosphaera pulchra HOL galea type. (c-e) Syracosphaera mediterranea HET and three alternative types of HOL cells: marisrubri, gracillima and hellenica. (f) HOL phase of Calcidiscus leptoporus subsp. quadriperforatus. The asterisks denote samples in which combination coccospheres were found (each bubble in the plots represents one sample, and the diameter of each bubble depends on the cell density according to the respective legend on the upper right side). Raw cell count data are available in Table S1.

McGrane, 2007; Geisen et al., 2002; Karatsolis et al., 2014; Triantaphyllou et al., 2016). All three holococcolithophores have similarly shaped BCs, which are elliptical with wellformed tubes, a flat distal cover and central boss, but they differ in the arrangement of the crystallites in the distal cover and in the number of larger perforations. Likewise, in all three cases the CFCs have an elevated transverse bridge. As in the case of Syracosphaera pulchra it is unclear whether the three morphotypes represent separate species that only show morphological differentiation in the holococcolith phase (cryptic speciation) or if they are intraspecific variants (Geisen et al., 2002).

In samples from the GoA, we observed three unambiguous combination coccospheres of $S$. mediterranea heterococcol- iths with holococcoliths of a fourth type that is very different to the wettsteinii, gracillima and hellenica types (Fig. 7a-c). Complete coccospheres of the fourth holococcolith-bearing type were also detected (Fig. 7d, e). The coccospheres are spheres of 13 to $18 \mu \mathrm{m}$ length. The holococcoliths of this variant are about 2 to $2.6 \mu \mathrm{m}$ long, consisting of an open tube with an indented wall open distally and subdivided by vertical septae. These septae define 6 to 10 pores, frequently including one or two central pores. The septae are higher in the center of the coccolith, giving the distal surface a domal shape, but there is no central boss. Possible CFCs were detected in a single complete coccosphere, with a more elevated central area than the other coccoliths (Fig. 7e, f). 

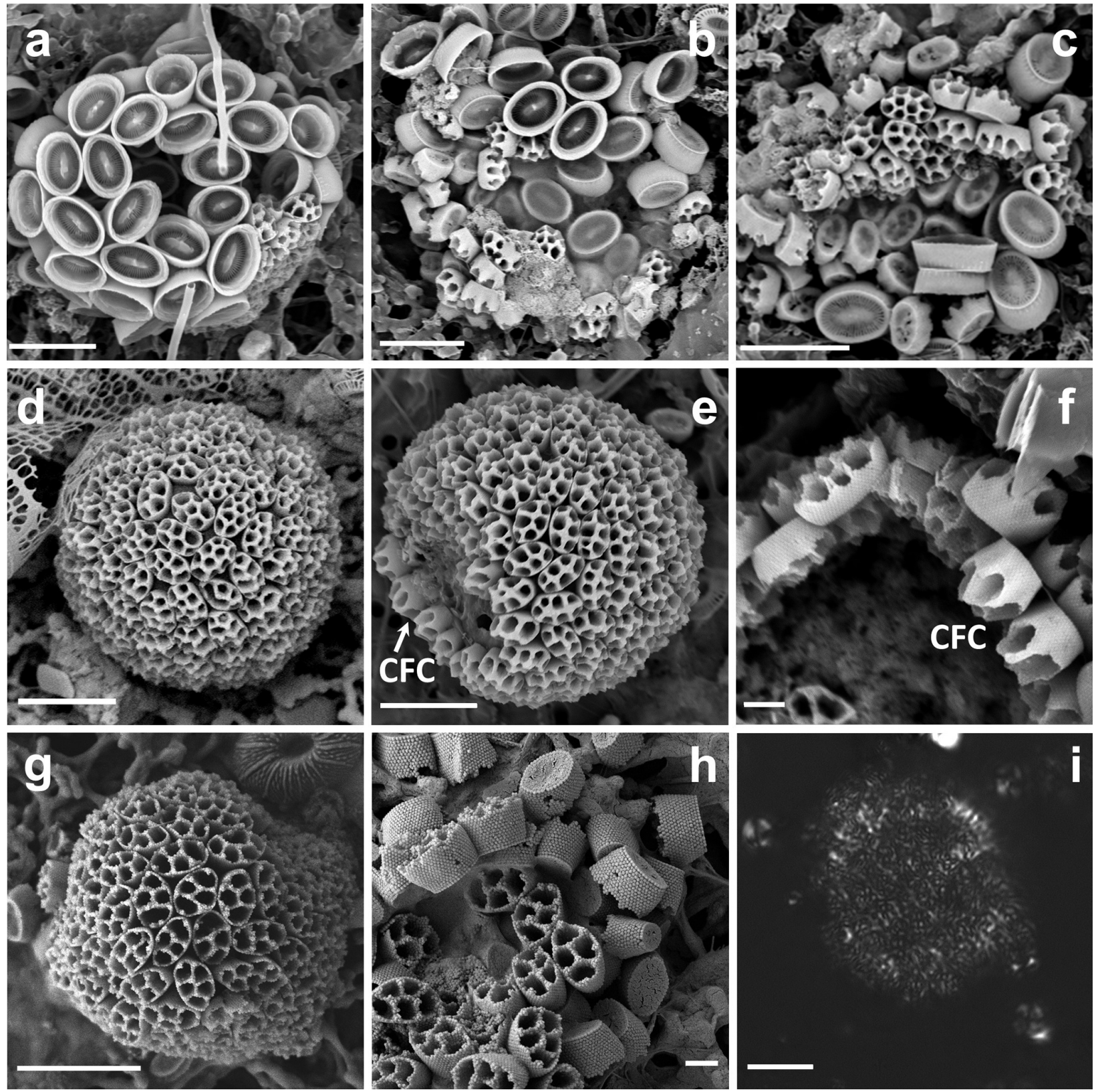

Figure 7. (a-c) Combination cells of Syracosphaera mediterranea with marisrubri-type HOL coccoliths (GoA, 29 October 2017 , 40 and $60 \mathrm{~m}$ ). (d, e) HOL marisrubri-type coccospheres (GoA, 13 December 2018, $100 \mathrm{~m}$, and 7 January 2021, $2 \mathrm{~m}$ ). (f) Coccoliths with 5-10 perforations showing irregular walls and a domal shape. Coccoliths at apical pole (circum-flagellar coccoliths) have higher walls (GoA, 18 March 2018, 29 m). (g) Coccosphere and (h) coccoliths of C. leptoporus HOL with four to six perforations and a higher and evenly high tube wall (GoA, 17 August 2017, 40 m). (i) Polarized light microscopy image of S. mediterranea HOL marisrubri (GoA, 16 December 2020, $2 \mathrm{~m})$. Scale bars: $5 \mu \mathrm{m}$, (f, h) $1 \mu \mathrm{m}$.

We informally refer to the newly described variant as $S$. mediterranea HOL marisrubri (mare: sea, rubrum: red) type in reference to the Red Sea where samples were collected. In addition to the specimens from this study we have found two other examples from the Gulf of Mexico: one illustrated by Agbali (2014, pl. 5, fig. 14) labeled as unknown and the other by Young et al. (2003, pl. 47, figs. 7-8) labeled as Syracol- ithus schilleri. In both cases those coccospheres appear to be monomorphic. 


\section{Discussion}

Young et al. (2003) recognized a distinctive subset of holococcolithophores with coccospheres that are monomorphic and coccoliths that are open tubes with internal septae (walls) extending down to the proximal surface. The tube wall shows hexagonal fabric, and the crystallites have radial $c$ axes (birefringent in plan view in light microscopy). The fabric of the septae is not obviously different, but they are nonbirefringent in plan view in LM (Fig. 7i), so the calcite crystallites must have vertical $c$ axes.

Although this group is distinctive in both SEM and LM, members of it have been shown to be formed by two very different and only distantly related species; Geisen et al. (2002) showed that Syracolithus quadriperforatus was the holococcolith stage of a large form of Calcidiscus leptoporus, and subsequently Frada et al. (2009) showed that Syracolithus schilleri was the holococcolith stage of Scyphosphaera apsteinii. Calcidiscus and Scyphosphaera respectively belong to the Calcidiscaeae and Pontosphaeraceae, and separation of these groups is well supported by paleontological, morphological and molecular genetic data, with an earliest common ancestor at least 65 million years ago (Medlin et al., 2008).

The Syracosphaera mediterranea HOL marisrubri type belongs to this group and could easily be confused with either Calcidiscus leptoporus subsp. quadriperforatus HOL or Scyphosphaera apsteinii HOL. Holococcoliths of the marisrubri type can be separated from those of Calcidiscus quadriperforatus HOL by having more perforations (5-10 vs. 4-6), a more domal distal surface, and a lower and irregular wall (Fig. $7 \mathrm{~g}$ ). They can be separated from those of Scyphosphaera apsteinii HOL by being smaller $(2-3 \mu \mathrm{m}$ vs. 3-4 $\mu \mathrm{m}$ ) with fewer pores (5-10 vs. 8-20), having a more domal distal surface and lacking a central boss.

Our demonstration that Syracosphaera mediterranea can produce marisrubri-type holococcoliths is very surprising in two respects. First, it indicates that the septate tube type of holococcolith has evolved independently in three separate lineages of coccolithophores. Secondly, whilst S. mediterranea had already been shown to form three different holococcolith morphotypes, these were all rather similar. The marisrubri HOL adds a fourth and, at least superficially, very different morphotype. Both results suggest that holococcolith morphology may be more plastic and even less reliable for large-scale taxonomy than had been thought previously.

\section{Distribution and ecology}

During our seasonal survey in the GoA, we observed for Syracosphaera mediterranea both the heterococcolithophore phase, $S$. mediterranea HET, and two common holococcolithophore types, $S$. mediterranea HOL marisrubri and $S$. mediterranea HOL gracillima, as well as rare cells of $S$. mediterranea HOL hellenica (Fig. 6d). However, while both gracillima and hellenica HOL appeared in relatively shal- low water layers during the stratified period together with the heterococcolithophore life cycle phase, the novel marisrubri type was predominantly detected during the colder winter mixing period. This indicates that marisrubri HOL is ecologically distinct from the other holococcolithophore variants, while its distribution pattern is opposite to the typical life cycle pattern in coccolithophores, in which heterococcolithophores tend to inhabit higher-nutrient, turbulent settings and holococcolithophores stable oligotrophic settings (e.g., Cros and Estrada, 2013; de Vries et al., 2021). The ecological peculiarity of the marisrubri type may indicate a case of cryptic speciation in $S$. mediterranea, whereby the difference between the two taxa would be apparent in the morphology of the holococcolith phase but cryptic in the heterococcolith phase. Combination cells of $S$. mediterranea HET$S$. mediterranea HOL marisrubri type were detected at the onset of the mixing period in October, which suggests that the life cycle transition is triggered in response to changing temperature and/or nutrient regime during seasonal turnover in the GoA (Fig. 6d). Finally, we note that the holococcolithophore phase of Calcidiscus leptoporus subsp. quadriperforatus that may be confused with the marisrubri HOL was also solely detected during the stratified period in the surface mixed layer, which further supports a separation between the two phenotypes (Fig. 6d).

\section{Syracosphaera lamina with Poricalyptra aurisinae}

Fig. 8a

We have observed a single coccosphere of this combination in a sample from the GoN collected on 5 July 2016 at $60 \mathrm{~m}$. The coccosphere is largely intact and well imaged, and both phases can be identified unambiguously. The holococcoliths are those of Poricalyptra aurisinae (Kamptner, 1941) Kleijne (1991) and consist of four circum-flagellar coccoliths and about 40 body coccoliths, most of which show the typical four transverse openings on the distal surface. A few of the body coccoliths show fewer regular openings, but similar body coccoliths do occasionally occur on P. aurisinae coccospheres as well. The heterococcolith is Syracosphaera lamina (Lecal-Schlauder, 1951), with about 14 body coccoliths visible and one likely exothecal coccolith (Fig. 8a, bottom right).

\section{Discussion}

Although we only have one specimen, it is a well-conserved combination coccosphere unlikely to have formed accidentally. Moreover, another Poricalyptra species, $P$. gaarderae, was recently shown by us (Keuter et al., 2019) to form combination coccospheres with Alveosphaera bimurata. Based on the structure of the body coccoliths and exothecal coccoliths we argued that it was closely related to S. lamina and reclassified it as Syracosphaera gaarderae. Poricalyptra is a rather distinct and well-separated genus, so we predict that 
the other two species (P. magnaghii and P. isselii) currently in the genus will prove to be the holococcolith stages of other Syracosphaera species, probably the ones with heterococcoliths similar to those of S. lamina (e.g., S. tumularis, S. rhombica).

\section{Systematics}

Poricalyptra aurisinae has priority over S. lamina, but Syracosphaera has priority over Poricalyptra. Hence, the name of the species should be Syracosphaera aurisinae, which we propose as a new taxonomic combination. Since P. aurisinae was the type species of Poricalyptra, Poricalyptra becomes a junior synonym of Syracosphaera. This nomenclature change leaves the other two species, P. magnaghii and $P$. isselii, as orphan taxa. Both species were originally described in Helladosphaera, so it would be appropriate to use the combinations Helladosphaera magnaghii Borsetti \& Cati 1976 and H. isselii Borsetti \& Cati 1976 until their heterococcolith phase is established.

\section{New combination}

Syracosphaera aurisinae Keuter, Koplovitz, Zingone, Young and Frada, nov. comb.

\section{Basionym}

Helladosphaera aurisinae Kamptner 1941 (p. 91, figs. 121124)

\section{Syracosphaera azureaplaneta with Corisphaera sp.}

Fig. 8b

We observed a single likely combination coccosphere of Syracosphaera azureaplaneta Young, Bown, Cros, Hagino \& Jordan heterococcoliths with a bridged holococcolith, which was collected in the GoN from surface water in March 2017 (Fig. 8b). The S. azureaplaneta coccoliths include both body and exothecal coccoliths and are unambiguously identifiable. The holococcoliths, however, are poorly formed and imperfectly imaged. They are clearly bridged holococcoliths seemingly belonging to Corisphaera, but this is a notoriously difficult set of species to identify and no reliable species identification is possible. However, it is interesting to note that similar bridged holococcoliths are known to be produced by Syracosphaera arethusae, which also has body coccoliths similar to those of $S$. azureaplaneta, the two species being classified together in the Syracosphaera pulchra group and dilatata type (Young et al., 2018). In this case there may be consistency of holococcolith forms between closely related species.

\section{Syracosphaera orbiculus with Corisphaera sp.}

Fig. 8c
Also, in this case our observations are based on a single likely combination coccosphere collected in the GoN in March 2017 at a depth of $20 \mathrm{~m}$. The heterococcoliths are four body coccoliths, and the identification as S. orbiculus cannot be confirmed but is very likely. The holococcoliths are bridged and the bridge is extended into a leaf in at least some specimens. Cros et al. (2000, pl. VIII fig. 6) illustrated a very similar combination coccosphere with a holococcolith they tentatively assigned to an informally described morphotype, Corisphaera sp. B. Given the similarities of our likely combination coccosphere and that of Cros et al. (2000) the association can now be considered established. Since the holococcolith stage was not formally described no change in terminology is needed.

\subsection{Novel species from the genus Ophiaster}

The genus Ophiaster Gran 1912 emend. Manton and Oates 1983 (family Syracosphaeraceae) is characterized by "armlike" appendages formed of strings of specialized asymmetric coccoliths (osteoliths) linked together by spoon- and tongue-like ends (Young et al., 2009). These appendages extend from the antapical end of the coccosphere but can also appear wrapped around the cell. The body coccoliths are small muroliths; the rim is narrow with a weak proximal flange, and the central area is floored by a radial lath cycle or vacant (O. minimus). The circum-flagellar coccoliths are similar to the body coccoliths but have spines. Body coccolith morphology places Ophiaster in the Syracosphaeraceae, yet both molecular data and life cycle information are missing.

Four Ophiaster species are currently recognized: $O$. formosus, O. hydroideus, O. minimus and $O$. reductus. Of these $O$. reductus and $O$. minimus are distinctive but rare. The vast majority of specimens are classified as $O$. hydroideus or $O$. formosus. These latter species have similar body coccoliths and can be separated on the basis of the shape of the osteoliths, which are typically more elongate in $O$. hydroideus. Yet, both species show significant variation and clear separation can be difficult. In GoA samples we frequently observed $O$. formosus and a novel distinctive morphotype that we describe here as a new species.

Ophiaster macrospinus Keuter, Koplovitz, Zingone, Young and Frada, sp. nov.

Fig. 9a-e

\section{Diagnosis}

An Ophiaster species with a dimorphic spherical coccosphere with weakly calcified elliptical body coccoliths. The circum-flagellar coccoliths display a distinct robust spine (ca. $2 \mu \mathrm{m})$ at the center. The radial, antapical appendages are composed of strings of coccoliths (>1.2 $\mu \mathrm{m}$ width). These are osteoliths of rounded rectangle shape. 

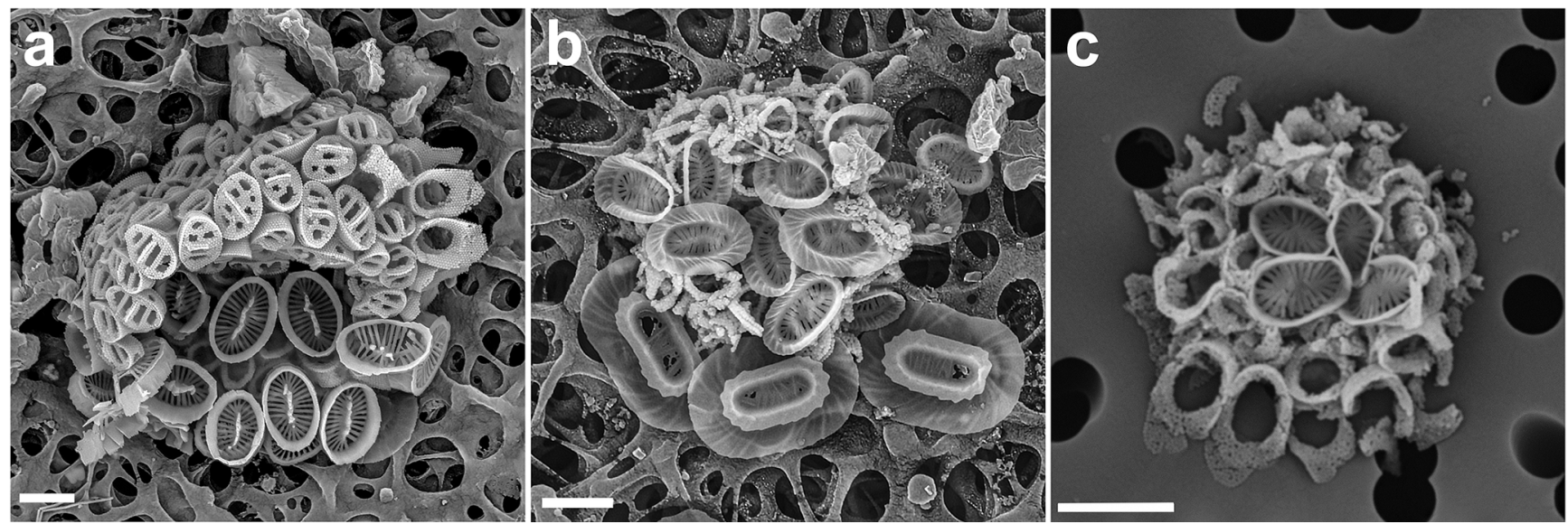

Figure 8. New combination coccospheres in the genus Syracosphaera. (a) Below are body coccoliths of S. lamina (and one exothecal coccolith in the bottom right), and above are Poricalyptra aurisinae body coccoliths with the typical four transverse openings and circumflagellar coccoliths (GoN, 12 August 2016, $60 \mathrm{~m}$ ). (b) S. azureaplaneta and Corisphaera sp. (GoN, 9 March 2017, $1 \mathrm{~m}$ ). (c) S. orbiculus with Corisphaera sp. (GoN, 28 March 2017, $20 \mathrm{~m})$. Scale bars: $2 \mu \mathrm{m}$.

\section{Material observed}

Specimens including complete coccospheres were found in samples from Station A in the GoA from August to November in deeper layers (see Fig. 11a).

\section{Holotype}

A specimen collected at Station A in the GoA on 11 September 2017 at a depth of $120 \mathrm{~m}$ (Fig. 9a) and deposited in the herbarium of the Hebrew University, Jerusalem, with the reference number HUJAL/805001.

\section{Etymology}

The name macrospinus refers to the prominent spines on the circum-flagellar coccoliths.

\section{Coccosphere and body coccoliths}

The observed coccospheres are all collapsed, and their diameters range between 4.5 and $7 \mu \mathrm{m}$. Individual body coccoliths are elliptical weakly calcified muroliths with a narrow rim, and the central area is floored by a radial lath cycle, similar but on average slightly smaller (length $1.2 \pm 0.1 \mu \mathrm{m}$, average area: $2.9 \pm 0.4 \mu \mathrm{m}^{2}$ ) than Ophiaster formosus in our samples (length $1.35 \pm 0.1 \mu \mathrm{m}$, average area: $3.8 \pm 0.7 \mu \mathrm{m}^{2}$ ) (Figs. 9f, 10a).

\section{Circum-flagellar coccoliths}

These are muroliths of the same type as the body coccoliths, but with a spine and taller rim wall (Fig. 9b, c, e). Circumflagellar coccoliths appear in groups of five or six at the apical pole of all cells observed. A distinct, robust pyramidal spine ca. $2 \mu \mathrm{m}$ high emerges from the center of the muroliths, which contrasts with $O$. formosus that has smaller, more delicate spines in the circum-flagellar coccoliths.

\section{Osteoliths}

These are very wide coccoliths $(1.6 \pm 0.1 \mu \mathrm{m})$ that are nearly rectangular with rounded edges. This feature clearly differentiates this morphotype from $O$. formosus, which has narrower osteoliths $(0.9 \pm 0.2 \mu \mathrm{m})$ as validated by morphometric measurements on specimens from both types in the same samples (Fig. 10b). Osteoliths in O. macrospinus have a nearly flat proximal face and a distal convex face. A thorn-like process can be detected on the edge of the shorter convex side of each osteolith (Fig. 9c). The proximal flat face of the osteoliths has a slit and a small orifice and is linked with the distal face of the next osteolith. The first link is differentiated from the others by having a broader end where it attaches to the coccosphere and a narrower end where it attaches to the next osteolith. The arms can either be wrapped around the coccosphere or deployed radially (Fig. 9a, c, d), as in other Ophiaster species (Young et al., 2009).

\section{Distribution}

Specimens of $O$. macrospinus were detected in the GoA during the oligotrophic stratified period from August to November at relatively low concentrations ( $\max 0.72$ cells $\mathrm{mL}^{-1}$ ) at sub-euphotic depths mostly $\geq 100 \mathrm{~m}$ (Fig. 11a). In contrast, cells from Ophiaster formosus were detected around the deep chlorophyll maximum $\leq 100 \mathrm{~m}$ during the stratified period and during the winter mixing period (Fig. 11b). This ecological differentiation between $O$. macrospinus and other congeneric species further supports the proposed taxonomic discrimination. To our knowledge other specimens likely to be $O$. macrospinus, but which have been affiliated with $O p h i$ - 

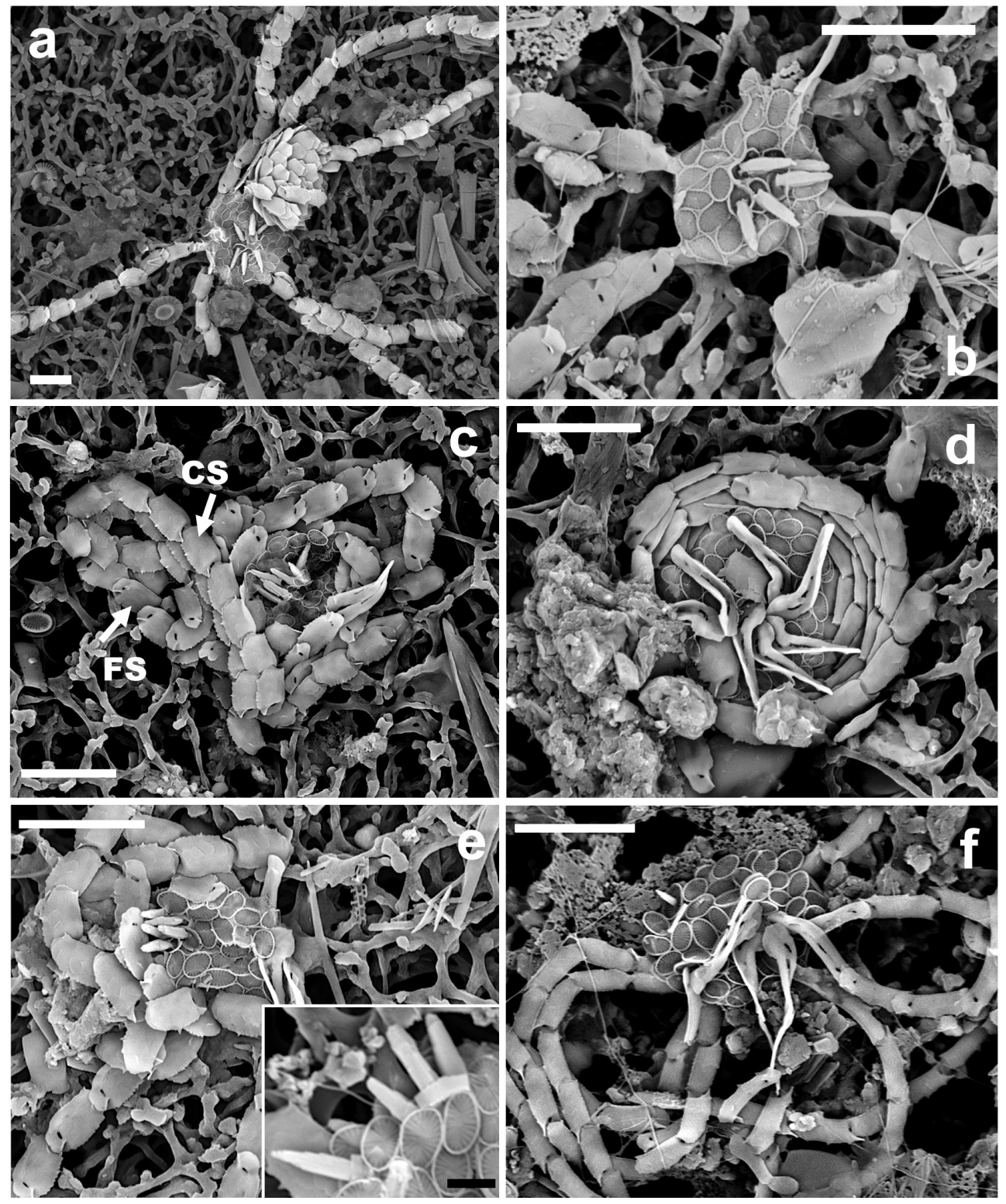

Figure 9. Ophiaster macrospinus. (a) Apical view with an overlapping Florisphaera coccosphere (GoA, 11 September 2017 , 120 m). (b) Apical view showing connection of body coccoliths, link coccoliths and osteoliths, as well as the difference in wall height between body and circum-flagellar coccoliths (GoA, 18 June 2017, $120 \mathrm{~m}$ ). (c) Arrows indicate the convex (CS) and the flat side (FS) of the osteoliths (GoA, 11 September 2017, $120 \mathrm{~m}$ ). (d) O. macrospinus wrapped arms, with a view of link coccoliths (GoA, 11 September 2017, 120 m). (e) View of coccosphere with body coccoliths, central spines and surrounding osteoliths. A close-up of the central robust spines is shown in the inset (GoA, 11 September 2017, $120 \mathrm{~m}$ and GoA, 17 August 2020, $120 \mathrm{~m}$ ). (f) Coccosphere of $O$. formosus with narrower osteoliths and smaller spines on circum-flagellar coccoliths (GoA, 18 October 2017, $80 \mathrm{~m}$ ). Scale bars: $5 \mu \mathrm{m}$, insertion: $1 \mu \mathrm{m}$.

aster formosus, were detected in other locations, namely by H. Andruleit from a depth of $80 \mathrm{~m}$ south of Java (Young et al., 2021)

\subsection{Genus Florisphaera}

Putative life cycle combination in Florisphaera profunda

Fig. 12

Florisphaera profunda Okada \& Honjo 1973 characteristically occurs in the deep photic zone, in the lower part of the thermocline, below the deep chlorophyll maximum, in tropi- 

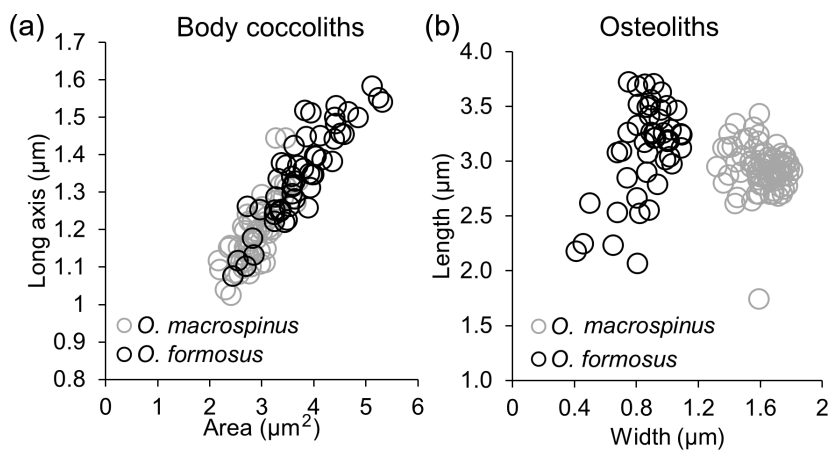

Figure 10. Comparative morphometry of Ophiaster macrospinus and Ophiaster formosus. (a) Body coccoliths, (b) osteoliths. Both species were collected in the GoA. Raw measurements of both osteoliths and body coccoliths are available in Table S2.

cal and subtropical regions (e.g., Quinn et al., 2005; Poulton et al., 2017). It is the only species of the genus Florisphaera, but it includes several morphological variants: var. profunda, var. elongata and var. rhinocera, which are distinguished by size and by details of processes (Quinn et al., 2005; Young et al., 2021). The coccosphere of $F$. profunda has an "artichokelike" form and is composed of numerous single-crystal platelike nannoliths. Given the preference of Florisphaera for sub-euphotic layers, it has been suggested that it may be heterotrophic rather than autotrophic (e.g., Molfino and McIntyre, 1990). However, in fresh LM preparations a chloroplast is normally visible in $F$. profunda cells even in normal illumination, and this is confirmed here with fluorescence microscopy (488 $\mathrm{nm}$ excitation, $630 \mathrm{~nm}$ emission) (Fig. 12a). The consistent presence of chloroplasts does not exclude the possibility that $F$. profunda may be mixotrophic, as has been shown for other coccolithophores (Godrijan et al., 2020; Avrahami and Frada, 2020).

Florisphaera profunda cells were detected in the GoA during the second half of the stratified period between 80 and $140 \mathrm{~m}$. At the same time and depth, we detected ca. 10 cells of a small holococcolithophore $(<2.5 \mu \mathrm{m}$ in diameter $)$ bearing flat, trapezium-shaped holococcoliths $1.1-1.3 \mu \mathrm{m}$ long tapering from $0.4-0.7 \mu \mathrm{m}$ wide to $0.6-0.9 \mu \mathrm{m}$ wide, composed of multiple rhombohedral crystallites. The narrower, proximal end has angular edges, whereas at the distal end is slightly rounded (Fig. 12b-d). Two of these holococcolithophore cells displayed an outer Florisphaera nannolith, each from a different variant (Fig. 12e, f).

Kleijne (1991, pl. XIX, figs. 2-3) detected and named as "holococcolithophorid type B" a virtually identical coccosphere. Based on the co-occurrence with Florisphaera and the similarity in shape she suggested "that they may be related and are stages in the life cycle of one and the same species". Our new observations support this inference, although it cannot be considered proven. We recommend re- ferring to the holococcolith as Holococcolithophore sp. cf. F. profunda.

\section{Discussion}

The affiliation of Florisphaera to the coccolithophores remains uncertain (incertae sedis), given both the lack of morphological attributes clearly relating it to other coccolithophores and molecular genetic data (Young et al., 2003). However, our observations provide first evidence for a life cycle involving a holococcolith-bearing cell, suggesting that Florisphaera may belong to one of the holococcolithophoreproducing clades within the calcihaptophytes rather than to an outer coccolithophore group (Hagino and Young, 2015; Frada et al., 2019). Moreover, this also represents the first case of an association of a nannolith-bearing phase with a holococcolithophore stage within a core clade of the coccolithophores.

\subsection{Family Papposphaeraceae}

The Papposphaeraceae Jordan \& Young, 1990 emend Andruleit \& Young 2010 are weakly mineralized and small coccolithophores producing simple, minute narrow-rimmed muroliths, mostly with prominent central structures that differ between genera. It originally included only the genera Papposphaera Tangen 1972 and Pappomonas Manton and Oates 1975. Subsequently, Andruleit and Young (2010) extended the family to include the genera Kataspinifera, Picarola, Vexillarius and Wigwamma. Additional genera have since been described by Thomsen et al. (2015), Thomsen et al. (2016d), and Thomsen and Østergaard (2015a): Formonsella, Porsilidia and Ventimolina as well as the heterococcolith stage of Quaternariella. A further likely Papposphaeraceae, fossil genus Pocillithus, was described by Dunkley Jones et al. (2009). Taxa of the family have mostly been detected in the Arctic and Antarctic and in the deep photic zone at lower latitudes. Chloroplasts have not been observed in these taxa (likely due to a secondary loss), while the presence of a long haptonema has suggested that they are heterotrophic and likely prey on bacteria (Thomsen et al., 2013). Life cycle pairs bearing holococcoliths have been detected in several species of Papposphaera, Pappomonas and Wigwamma from the observation of combination coccospheres (e.g., Thomsen et al., 1991, 2013). No molecular genetic data are available for this group. Yet, the fact that they form both typical holococcoliths and heterococcoliths in alternate life cycle stages indicates that they likely belong to the clade of holococcolith-producing coccolithophores (Young et al., 2005; Andruleit and Young, 2010).

Pappomonas vexillata Keuter, Young, Koplovitz, Zingone and Frada sp. nov.

Fig. 13 

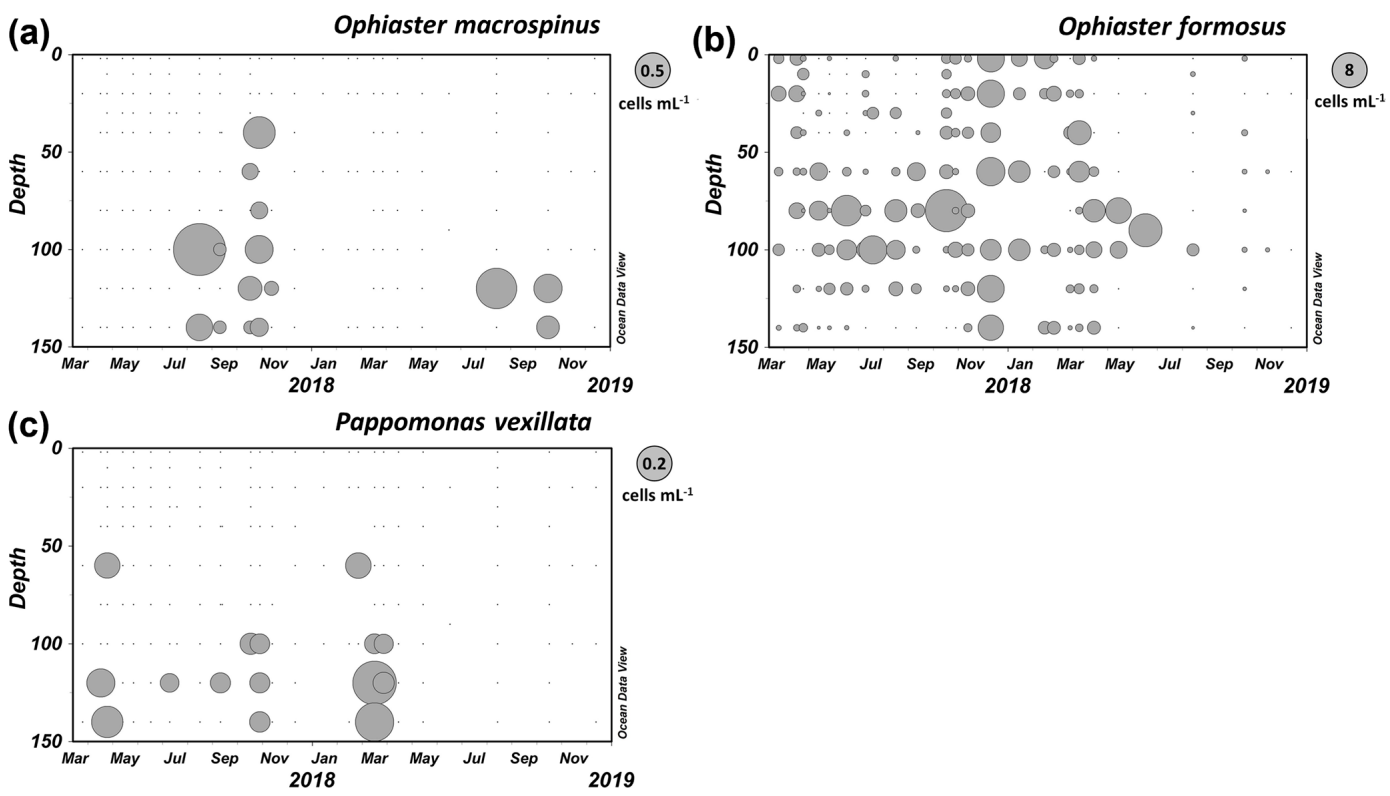

Figure 11. Distribution of coccolithophores at "Station A" in the GoA between March 2017 and December 2018. (a, b) Distribution of Ophiaster macrospinus and Ophiaster formosus, and (c) of Pappomonas vexillata. Raw cell count data are available in Table S1.

\section{Diagnosis}

A papposphaeracean species with a dimorphic coccosphere. All coccoliths bear leaf-like appendages. The flattened calyxes consisting of two dissimilar elements are held in a tilted position with reference to the central process. The appendages of the CFCs are higher and bear two blade-like elements, while those of the $\mathrm{BC}$ are smaller and bear triangular and rod-shaped elements.

\section{Material observed}

The description is based on close observation of 15 specimens. Yet, this species was routinely observed in our 2-year survey (Fig. 11c).

\section{Holotype}

Figure 13a, GoA, Station A. The sample was collected on 26 April 2017 at a depth of $140 \mathrm{~m}$, and the specimen is deposited in the herbarium of the Hebrew University, Jerusalem, with the reference number HUJAL/805002.

\section{Etymology}

The name vexillata is an adjective derived from the Latin vexillum (flags or banners) meaning "provided with flags" in reference to the appendages of the coccoliths.

\section{Coccospheres}

All observed dimorphic coccospheres were collapsed. The estimated length of the intact coccospheres is $4-6 \mu \mathrm{m}$, and the estimated number of coccoliths is 55-60.

\section{Body and circum-flagellar coccoliths}

Coccoliths are round to slightly elliptical and $0.8(-1) \times 1$ $(-1.2) \mu \mathrm{m}$ in size. The rim is formed by cycles of rodshaped elements and spade-shaped pentagonal elements $(0.12-0.2 \mu \mathrm{m}$ wide and $0.12-0.16 \mu \mathrm{m}$ high), giving the rim a serrated aspect (Fig. 13c). In the central area, a cross-shaped central calcification leads to a process, which increases from 0.2 to $2.8 \mu \mathrm{m}$ in length from the antapical pole coccoliths to those at the apical pole (CFCs) ones.

The appendages have a leaf-like shape and are held in a tilted position with reference to the central process. They are comprised of two very differently sized elements. In the BCs the left element (in dorsal view) is a long rod aligning with the left long side of the fan-like second element with a convex and irregularly serrated upper border (Fig. 13c). Again, the size of the calyces increases with distance from the antapex so that the stick-like element has a length in the range of 0.5 to $1.3 \mu \mathrm{m}$. Both elements of the CFCs are blades; the left one is narrow $(0.35-0.8 \mu \mathrm{m})$, and the right element is a hypertrophied trapezoid and, in some cases, almost square $(1-1.9 \mu \mathrm{m}$ width). Both have a length of 0.8 to $2.6 \mu \mathrm{m}$ (Fig. 13d). 


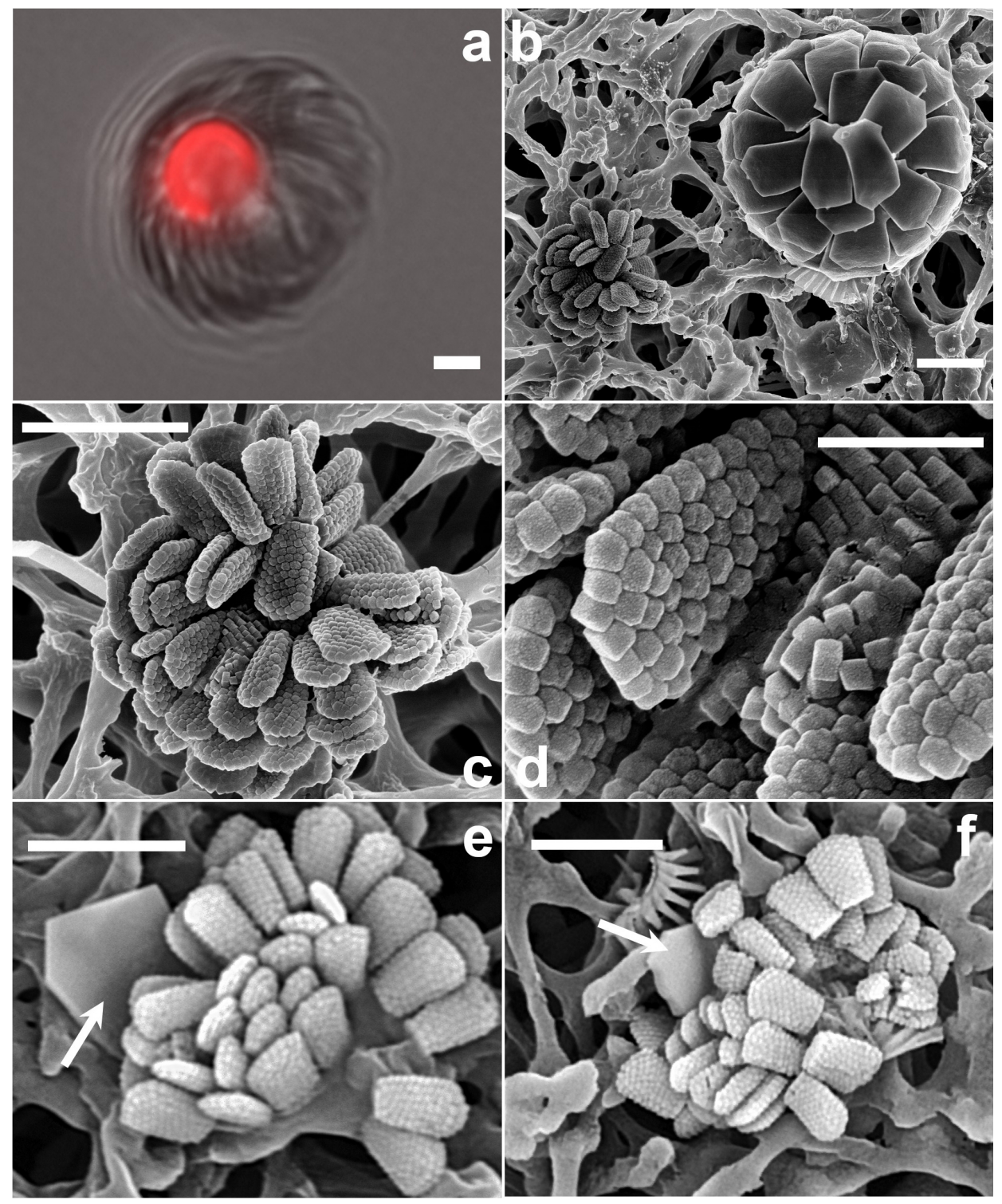

Figure 12. Florisphaera profunda. (a) Phase-contrast and epifluorescence micrograph images taken from fresh a Florisphaera cell depicting the chloroplast auto-fluorescence in red $(490 / 630 \mathrm{~nm}$, excitation / emission). Fluorescent chloroplast in a coccosphere (GoA, $17 \mathrm{Au}-$ gust 2020, $120 \mathrm{~m}$ ). (b) HET (right) and putative HOL (left) in close vicinity on the filter. (c) Coccosphere and (d) close-up of coccoliths of Holococcolithophore sp. cf. F. profunda (b-d from GoA, 11 September 2017, $120 \mathrm{~m}$ ). (e, f) Holococcolithophore coccospheres with nannoliths of two different variants of $F$. profunda (arrows) (GoA, 17 August and 11 September 2017, $120 \mathrm{~m}$ ). Scale bars: $2 \mu \mathrm{m}$, close-up of coccoliths at $500 \mathrm{~nm}$.

\section{Affinities}

The described coccolithophore is reminiscent of species of the genera Pappomonas and Ventimolina (Thomsen et al., 2015) with respect to the flattened calyx, with the twodimensional plate made up of adjoining elements (two in core species of Pappomonas and four in Ventimolina). In contrast, the core feature of Papposphaera is a three-dimensional calyx (Thomsen and Østergaard, 2014).

A further similarity to the core species of both Pappomonas and Ventimolina is the marked hypertrophy of one element of the calyx, as also found in P. weddellensis Thomsen in Thomsen et al. (1988) and Ventimolina stellata Thomsen. With representatives of Papposphaera and especially Ventimolina, Pappomonas vexillata shares the variomorphic coccosphere with all coccoliths bearing processes. This has been a key feature distinguishing these genera from Pappomonas, which has polymorphic coccospheres, yet exceptions have been described, e.g., in the case of Pappomonas garrisonii, which, however, could be clearly affiliated with 

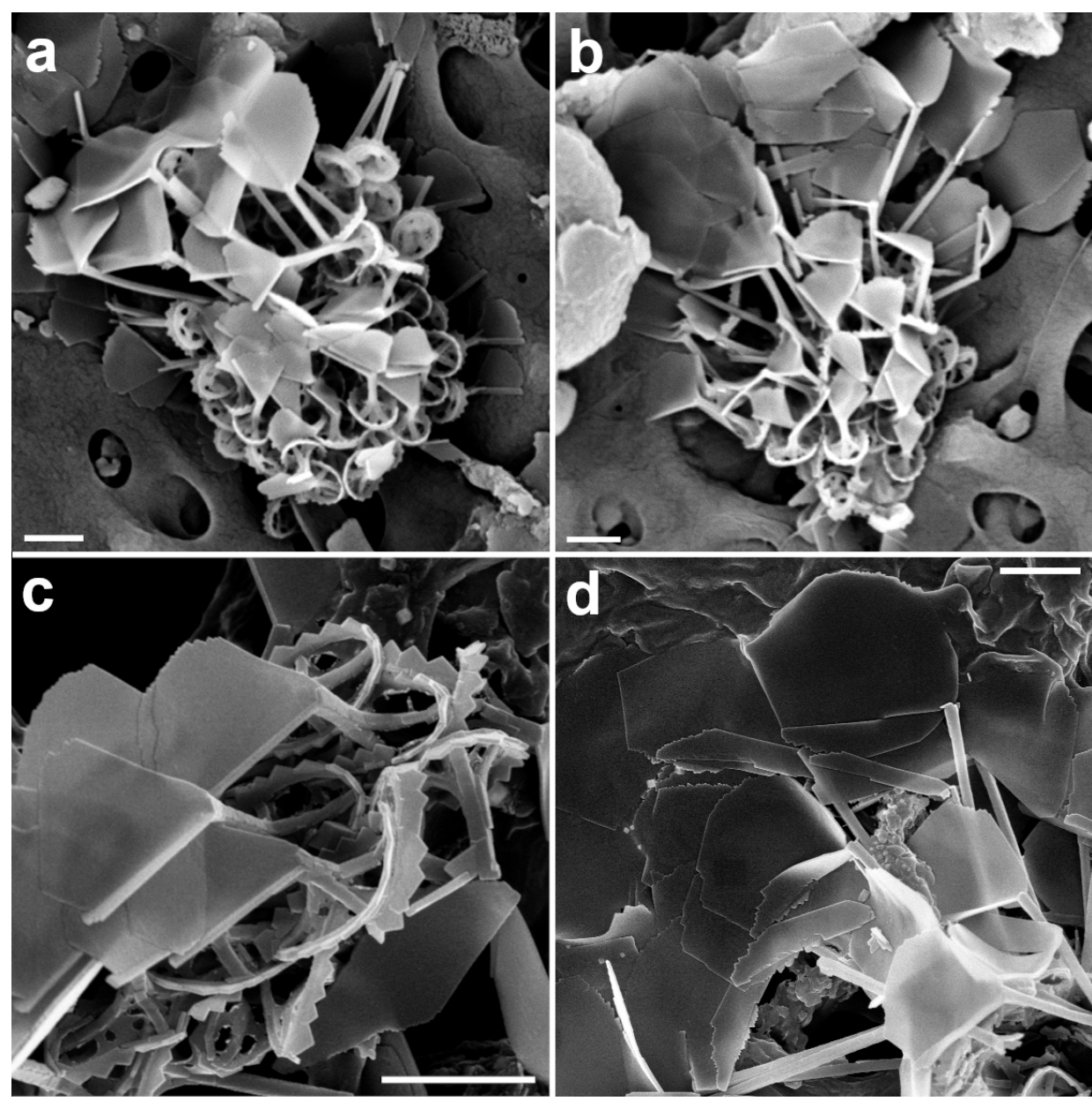

Figure 13. Pappomonas vexillata. (a, b) Complete coccospheres (GoA, 18 April 2017, 140 and 60 m). (c) Close-up of body coccoliths showing the two-tiered calyx with a triangular blade and a stick-like element on the left, as well as the central area and rim structure on the right side. (d) Circum-flagellar coccoliths with long processes and the two types of unevenly sized blade-like elements (c, d: GoA, 11 September $2017,120 \mathrm{~m})$. Scale bars: $1 \mu \mathrm{m}$.

Pappomonas based on its HOL life cycle phase (Thomson and Østergaard, 2014).

P. vexillata has in common with Pappomonas and Papposphaera, but not Ventimolina, a rim comprised of a cycle of elongated elements and an upper cycle of larger pentagonal elements that give the coccoliths a characteristic serrated distal margin (Fig. 13c). In Ventimolina the rim is reduced to the elongated elements only (Thomson et al., 2015), which is a major feature for the differentiation of the new genus from Pappomonas.

Based on the bidimensional calyx and serrated distal margin of the coccoliths, we assign the new species to the genus Pappomonas. The taxonomy of Papposphaeraceae, however, is an ongoing process awaiting the description of many more species for a better systematization of these lightly calcified coccolithophores.

Because presently the monospecific genus Ventimolina is still not an official emendation to the Papposphaeraceae
(Thomson et al., 2015), we also propose leaving the allocation of $P$. vexillata in the genus Pappomonas as tentative. For a better understanding of the relationships within and among groups of Papposphaeraceae, we strongly encourage further descriptions of species of these enigmatic deep-dwelling coccolithophores, as has been advanced by several recent publications that revisited polar specimens of Papposphaeraceae, including life cycle phases, but also described new genera from tropical waters (Thomson et al., 2016a-d; Thomson and Egge, 2016; Thomsen and Østergaard, 2014, 2015b, 2016; Thomsen et al., 2015, 2013).

\section{Distribution}

Like other warm-water species of Papposphaeracae, $P$. vexillata was mostly recorded in the deep ranges $>100 \mathrm{~m}$ in the GoA (Fig. 11c). A seasonality was noted with peaks in early spring, reaching 0.2 cells $\mathrm{mL}^{-1}$ in March $(120 \mathrm{~m})$. However, $P$. vexillata was restricted neither to those depths nor to the 
relatively colder spring water temperatures, and it was also detected in low concentrations in the first summer and autumn of our survey. It has to be noted that the water temperature in the GoA does not drop below $20^{\circ} \mathrm{C}$ throughout the $150 \mathrm{~m}$ water column, which increases the distribution range of papposphaeraceans. A further specimen of $P$. vexillata was also found in the eastern Mediterranean in a sample collected in April at a depth of $110 \mathrm{~m}$ offshore of Israel (personal observation of Keuter and Frada, 2018).

\subsection{New observations of combination coccospheres involving members of the family Papposphaeraceae}

\section{Picarola margalefii with Papposphaera sp, cf. polybotrys}

Fig. 14a

We found one likely combination coccosphere consisting of two heterococcoliths of Picarola margalefii and multiple undescribed holococcoliths resembling Papposphaera polybotrys (Fig. 14a). We also found coccospheres with similar holococcoliths (Fig. 14b). The P. margalefii heterococcoliths are readily identified by the banana-shaped central process, whilst the short length of these processes $(1-2 \mu \mathrm{m})$ indicates that they are body coccoliths. The holococcoliths appear to consist of a mix of circular body coccoliths and larger holococcoliths with a central process ending in a broadly flaring paddle-shaped structure. The most similar known holococcolithophore is $P$. polybotrys (formerly Turrisphaera polybotrys). This species produces similar CFCs but the BCs have a low process with a widely flaring end. It is possible that the BCs on our coccosphere are like the latter, but no clear examples are seen. In addition, $P$. polybotrys is only known from Arctic samples, with water temperatures of ca $5^{\circ} \mathrm{C}$, so it seems an unlikely species to occur in the warm waters $\left(>20^{\circ} \mathrm{C}\right)$ of the GoA.

\section{Discussion}

Given the uncertainty in the identification of the holococcolith, we refrain from any taxonomic revision. Our observations, however, do suggest that Picarola produces holococcoliths similar to those of Papposphaera, and this supports the placement of the genus in the family Papposphaeraceae, as suggested by Andruleit and Young (2010).

Papposphaera sp. with unidentifiable holococcolith

Fig. 14c

We found a likely combination coccosphere involving eight Papposphaera heterococcoliths and a mass of holococcolith calcite (Fig. 14c). The heterococcoliths are relatively elliptical muroliths with the serrated rim typical of Papposphaera and Pappomonas, an axial cross, and spines ending in simple tips. Papposphaera arctica forms similar body coccoliths, but definitive identification is not possible without circum-flagellar coccoliths, while it is known that there are many undescribed low-latitude species of Papposphaeraceae (e.g., Cros and Fortuño, 2002). The holococcolith material is partially collapsed but appears to consist of sheets of crystallites similar to those seen on the Picarola combination coccosphere (Fig. 14a).

\subsection{Novel holococcolithophore forms}

Calyptrosphaera lluisae Keuter, Young, Koplovitz, Zingone \& Frada sp. nov.

Fig. 15

Calyptrosphaera sp. (smaller heimdaliae) Cros \& Fortuño 2002 Fig. 93C, D

\section{Diagnosis}

Coccospheres are weakly dimorphic, spherical, $8-11 \mu \mathrm{m}$ diameter. Body coccoliths are elliptical calyptroliths 2.2$2.4 \mu \mathrm{m}$ long and $0.8-1.2 \mu \mathrm{m}$ wide, consisting of a tube and a low conical to dome-shaped distal cover. Tube imperforate, weakly flaring, four crystallites high (ca. $0.4 \mu \mathrm{m}$ ), sharply separated from the distal cover. At the base of the cover there is a cycle of 18 to 20 pores separated from each other by struts one crystallite wide. The rest of the cover is imperforate, except for a single circular small (ca. $0.2 \mu \mathrm{m})$ apical pore, which is visible on most coccoliths. Crystallites are rather irregular in shape and arrangement. Likely circumflagellar coccoliths, similar to BCs but with a substantially higher distal cover (total height 1.4-1.7 $\mu \mathrm{m}$ ) were observed on only a few coccospheres (Fig. 15f). In these putative CFCs often two rows of pores at the base of the BCs were observed. This feature was also observed in all coccoliths of some specimens (Fig. 15c). However, this may represent a different coccolithophore species.

\section{Material observed}

Images of 16 specimens were used for the description; many more were counted during our survey in the Gulf of Naples in a total of 8 samples from the surface (31 May, 14 June, 5 July, 25 August, 20 September 2016, 6 June 2017) and from 10 and $60 \mathrm{~m}$ (14 June 2016).

\section{Holotype}

Figure 15a shows a specimen from surface water in the GoN at the LTER-MC site on 14 June 2016. The specimen is deposited in the herbarium of the Hebrew University, Jerusalem, with the reference number HUJAL/805003. 

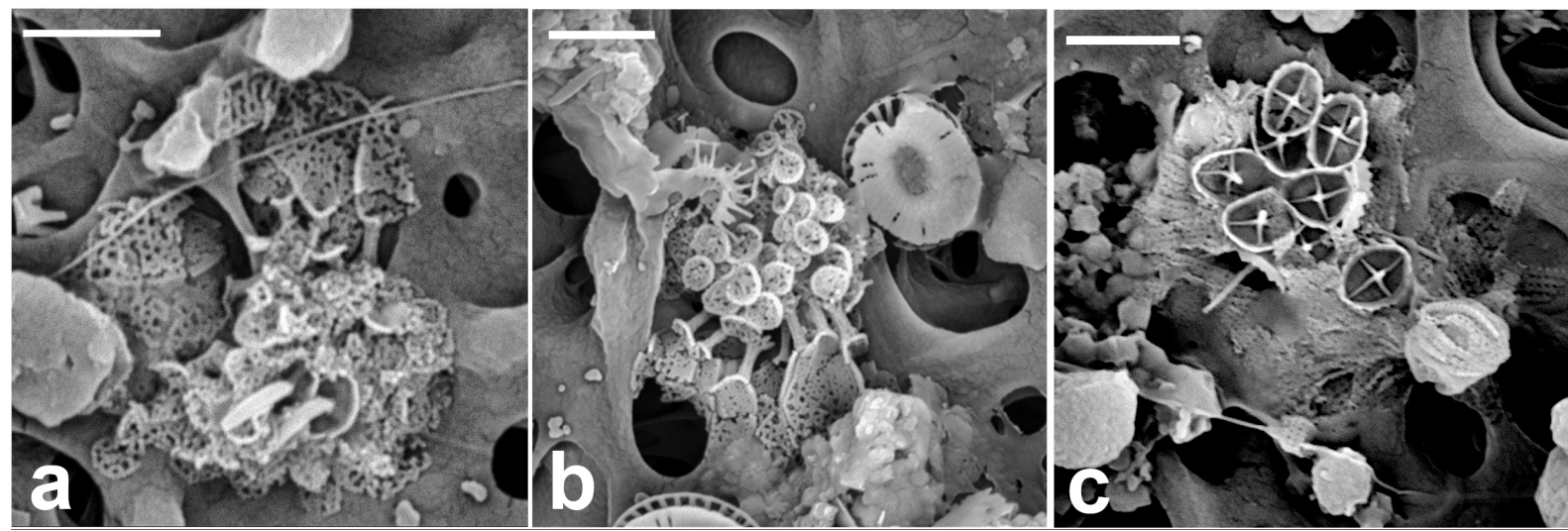

Figure 14. (a) Combination cell of Picarola margalefii. (b) Papposphaera polybotrys-like HOL. (c) Combination cell of Papposphaera sp. (a: GoA, 18 April 2017, $120 \mathrm{~m}$ and b, c: $140 \mathrm{~m}$ ). Scale bars: $2 \mu \mathrm{m}$.

\section{Etymology}

The epithet lluisae is in honor of Dr. Lluisa Cros, who first documented this species (Cros and Fortuño, 2002) and who has contributed important discoveries of coccolithophore biology and ecology.

\section{Distribution}

In the GoN C. lluisae occurred for a short time in high numbers (up to 65 cells $\mathrm{mL}^{-1}$ ) in late spring (mid-June) at the surface and at $60 \mathrm{~m}$ depth. Cros and Fortuño (2002) found this holococcolithophore in the western Mediterranean off Spain at the surface and a depth of $5 \mathrm{~m}$.

\section{Affinities and discussion}

As noted by Cros and Fortuño (2002), this species is similar to $C$. heimdaliae, which, however, has coccoliths with higher covers, wider openings and crystallites arranged in a hexagonal meshwork pattern. Overall, the two species can be readily distinguished, yet morphological resemblances clearly indicate they are closely related. Importantly, $C$. heimdaliae has been proposed to be the holococcolithophore life cycle phase of the Rhabdosphaeraceae species Cyrtosphaera aculeata (Triantaphyllou et al., 2016). Furthermore, Šupraha et al. (2018) observed a poorly preserved Rhabdosphaera xiphos combination coccosphere-bearing holococcolith suggested to be Calyptrosphaera dentata. It is therefore conceivable that $C$. lluisae is also linked to Cyrtosphaera or at least to the Rhabdosphaeraceae.

Calicasphaera bipora Keuter, Young, Koplovitz, Zingone \& Frada sp. nov.

Fig. 16a, b

Holococcolithophore Yang et al. 2001, plate 1, fig. 2 and 3.

\section{Diagnosis}

Coccosphere is monomorphic, ellipsoidal, $8-10 \mu \mathrm{m}$ long, formed of ca. 80-90 coccoliths. Coccoliths are elliptical open tubes, flaring distally (calicaliths; Kleijne, 1991). The outer layer of the tube is formed of regular calcite rhombohedra with a small proximal flange at the base, consisting of a single ring of crystallites. Inside the tube, less regular crystallites occur, filling it with the exception of two large irregular pores at the ends of the longitudinal axis. The coccoliths are $1.4-1.8 \mu \mathrm{m}$ long, $1-1.15 \mu \mathrm{m}$ wide and $0.6-0.8 \mu \mathrm{m}$ high.

\section{Material observed}

Images of five specimens were used for the description; three from the GoA, one from IODP359-P26 and one from Yang et al. (2001).

\section{Holotype}

Figure 16a, water sample from Station A, collected on 18 June 2018 and incubated for $4 \mathrm{~d}$. The specimen is deposited in the herbarium of the Hebrew University, Jerusalem, with the reference number HUJAL/805004.

\section{Etymology}

Bipora: the epithet "bipora" (two pores) refers to the two perforations in the holococcoliths.

\section{Distribution}

Found only in incubations of a water sample collected from Station A, 20 m, in June 2017, and surface waters, November 2018, from the IUI pier (coastal; $4 \mathrm{~m}$ deep). 


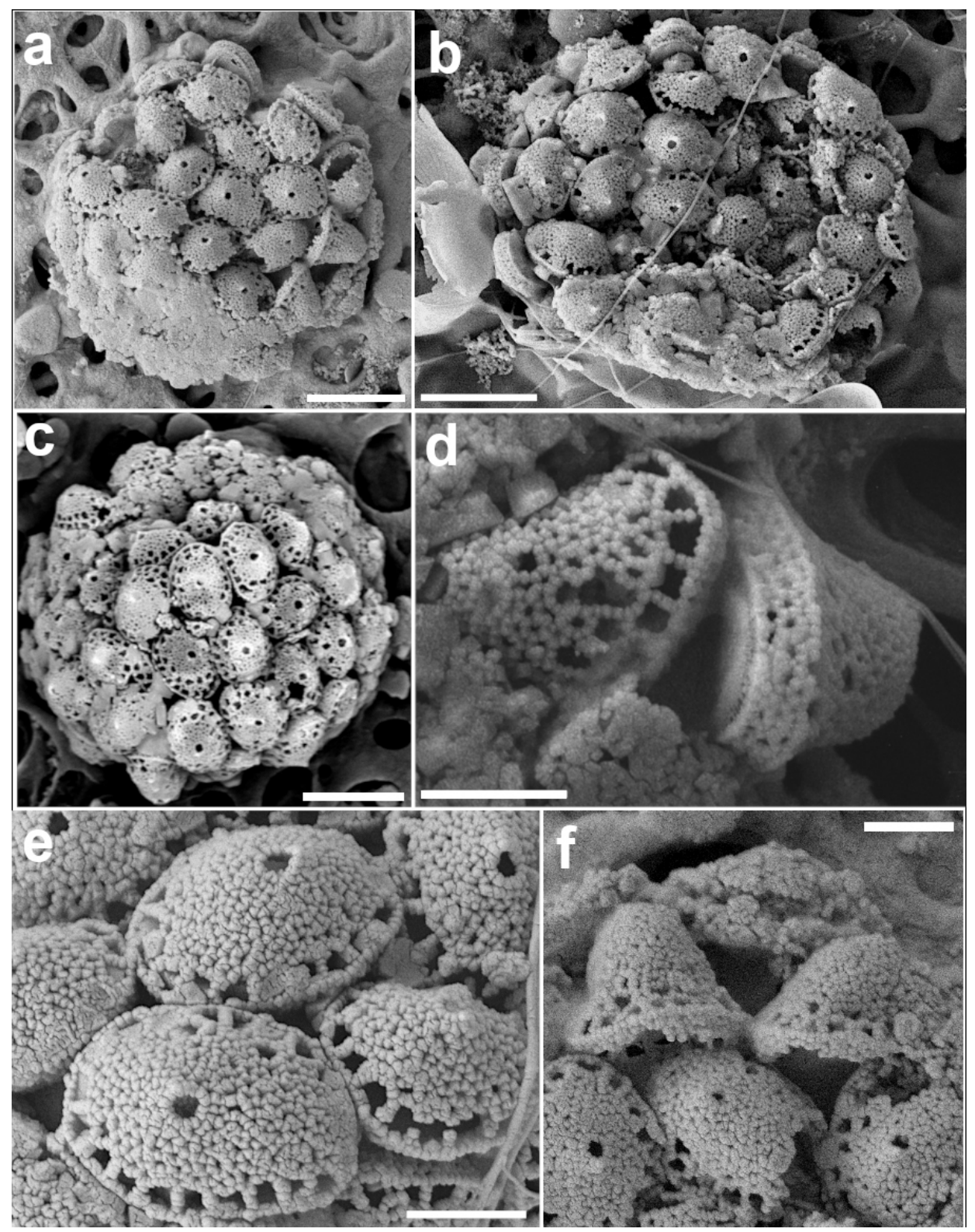

Figure 15. Calyptrosphaera lluisae. (a) Coccosphere with body coccoliths and a couple of putative circum-flagellar coccoliths at the bottom right of the image. (b) Coccospheres with BCs. (c) Specimen with mostly two rows of pores at the base of the distal cover; the scale bars in (a) - (c) are $3 \mu \mathrm{m}$. (d) Coccoliths in side view with tube walls ca. four crystallites high. (e) Distal view of body coccoliths and (f) of circum-flagellar coccoliths with higher covers; scale bars: $1 \mu \mathrm{m}$ (all images from sample GoN, 14 June 2016, $1 \mathrm{~m}$ ).

\section{Affinities}

The coccoliths are clearly calicaliths, i.e., tubes with an open distal end without a process. The irregular appearance of the inner crystallites of Calicasphaera bipora calicaliths is reminiscent of those of $C$. blokii, which, however, have a single opening in the center of the tube, are smaller $(1-1.5 \mu \mathrm{m})$ and are formed of larger crystallites.

\section{Holococcolithophore A}

Fig. 16c

\section{Diagnosis}

Coccosphere is monomorphic, sub-spherical, 6-7 $\mu \mathrm{m}$ in diameter. Holococcoliths are elliptical open tubes with very thick $(0.3-0.4 \mu \mathrm{m})$ walls of hexagonal mesh fabric, ca. $0.45 \mu \mathrm{m}$ high, ca. $1.7 \mu \mathrm{m}$ long and $1.1 \mu \mathrm{m}$ wide. The distal rim of the wall forms six to seven elevations. 

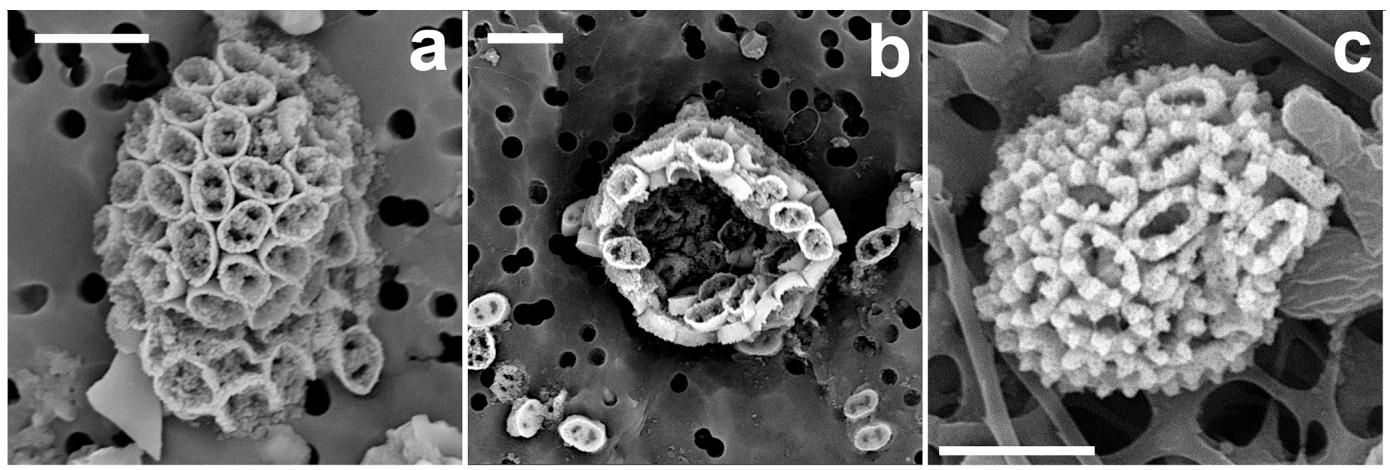

Figure 16. Novel holococcolithophores. (a, b) Calicasphaera bipora (incubated water sampled in the GoA, 18 June 2018 , $20 \mathrm{~m}$ ). (c) Holococcolithophore A (GoN, 30 November 2016, $10 \mathrm{~m})$. Scale bars: $3 \mu \mathrm{m}$.

Material

Only one specimen was found at a depth of $10 \mathrm{~m}$ at the LTER-MC station on 30 November 2016.

\section{Discussion}

This appears to be an undescribed form, but with only one specimen we prefer not to describe it. It is similar to Syracolithus sp. type A of Kleijne (1991), which, however, has additional rings of crystallites filling the central area.

\section{Conclusions}

Here we described a series of heterococcolithophores, holococcolithophores and life cycle combinations from the families Syracosphaeraceae and Papposphaeraceae as well as the genus Florisphaera. The new taxa and combinations were detected either in the GoA or the GoN as part of multi-annual surveys of coccolithophores (our unpublished research). Overall, this set of new observations further extends our knowledge of coccolithophore diversity and life cycle and will facilitate taxonomic studies and data interpretations in ecological research.

Data availability. All data in this study are provided in the paper or provided in the Supplement.

Supplement. The supplement related to this article is available online at: https://doi.org/10.5194/jm-40-75-2021-supplement.

Author contributions. SK and MJF conceptualized the study. SK, JRY, GK, AZ and MJF acquired the data and performed the formal sample analyses and imaging. MJF supervised the study. Resources were provided by MJF and AZ. All authors contributed to the writing and editing of the paper.
Competing interests. The authors declare that they have no conflict of interest.

Disclaimer. Publisher's note: Copernicus Publications remains neutral with regard to jurisdictional claims in published maps and institutional affiliations.

Acknowledgements. We gratefully thank the crew of the RV Sam Rothberg for logistic help during cruises in the GoA, as well as the Israel National Monitoring Program (NMP) and Vitaly Gutkin for operating the Magellan 400L SEM at the Center for Nanoscience and Nanotechnology at the Hebrew University of Jerusalem. We thank the personnel of MEDA (SZN) and the MB Vettoria crew for sampling at the LTER-MC site, Ferdinando Tramontano for preparing the coccolithophore filters, and Franco Iamunno, Giovanni Gragnaniello and Rita Graziano for the supervision on the JOEL 6700 at the Stazione Zoologica Anton Dohrn. We sincerely acknowledge Kyoko Hagino and Richard W. Jordan for reviewing and providing key insights that improved the quality of the paper.

Financial support. This work was supported by the Israel Science Foundation under grant nos. 1236/16 and 1238/16, both attributed to Miguel J. Frada, and by the European Union's Horizon 2020 research and innovation program under grant agreement no. 730984 (ASSEMBLE Plus project), attributed to Sabine Keuter and Adriana Zingone.

Review statement. This paper was edited by Emanuela Mattioli and reviewed by Richard W. Jordan and Kyoko Hagino.

\section{References}

Agbali, A.: Investigations of the ecology of calcareous nannoplankton and nannofossils in the north-east Gulf of Mexico to help establish a baseline for environmental impact studies, $\mathrm{PhD}$ thesis, Florida State University, 2014. 
Andruleit, H. and Young, J. R.: Kataspinifera baumannii: a new genus and species of deep photic coccolithophores resembling the non-calcifying haptophyte Chrysochromulina, J. Micropalaeontol., 29, 135-147, https://doi.org/10.1144/0262821X10-006, 2010.

Avrahami, Y. and Frada, M. J.: Detection of phagotrophy in the marine phytoplankton group of the coccolithophores (Calcihaptophycidae, Haptophyta) during nutrient-replete and phosphate-limited growth, J. Phycol., 56, 1103-1108, https://doi.org/10.1111/jpy.12997, 2020.

Billard, C.: Life cycles, in The Haptophyte Algae. Systematics Assoc. Spec., Vol. 51, edited by: Green, J. C. and Leadbeater, B. S., 167-186, Clarendon Press, Oxford, 1994.

Borsetti, A. and Cati, F.: Il nannoplancton calcareo vivente nel Tirreno Centro-meridionale, parte II., Giorn. Geol., 40, 209-240, 1976.

Bown, P., Lees, J., and Young, J.: Coccolithophores, Bown, P.R. Lees, J.A. Young, J. R. Calcareous nannoplankton evolution and diversity through time, Thierstein, H. R. Young, J. R., Coccolithophores from molecular processes to global impact, Springer Verlag, Berlin, Germarny, 83 pp., https://doi.org/10.1007/978-3662-06278-4_18, 2004.

Broecker, W. and Clark, E.: Ratio of coccolith $\mathrm{CaCO}_{3}$ to foraminifera $\mathrm{CaCO}_{3}$ in late Holocene deep sea sediments, Paleoceanography, 24, PA3205, https://doi.org/10.1029/2009PA001731, 2009.

Carrada, G. C., Hopkins, T. S., Bonaduce, G., Ianora, A., Marino, D., Modigh, M., Ribera, D. M., and di Scotto, C. B.: Variability in the hydrographic and biological features of the Gulf of Naples, Mar. Ecol., 1, 105-120, https://doi.org/10.1111/j.14390485.1980.tb00213.x, 1980.

Charlson, R. J., Lovelock, J. E., Andreae, M. O., and Warren, S. G.: Oceanic phytoplankton, atmospheric sulphur, cloud albedo and climate, Nature, 326, 655-661, https://doi.org/10.1038/326655a0, 1987.

Cianelli, D., D’Alelio, D., Uttieri, M., Sarno, D., Zingone, A., Zambianchi, E., and Ribera d'Alcalà, M.: Disentangling physical and biological drivers of phytoplankton dynamics in a coastal system, Sci. Rep.-UK, 7, 15868, https://doi.org/10.1038/s41598017-15880-x, 2017.

Cortés, M. Y. and Bollmann, J.: A new combination coccosphere of the heterococcolith species Coronosphaera mediterranea and the holococcolith species Calyptrolithophora hasleana, Eur. J. Phycol., 37, 145-146, https://doi.org/10.1017/S0967026201003523, 2002.

Cros, L. and Fortuño, J. M.: Atlas of Northwestern Mediterranean Coccolithophores, Sci. Mar., 66, 1-182, https://doi.org/10.3989/scimar.2002.66s11, 2002.

Cros, L. and Estrada, M.: Holo-heterococcolithophore life cycles: ecological implications, Mar. Ecol.-Prog. Ser., 492, 57-68, https://doi.org/10.3354/meps10473, 2013.

Cros, L., Kleijne, A., Zeltner, A., Billard, C., and Young, J. R.: New examples of holococcolith - heterococcolith combination coccospheres and their implications for coccolithophorid biology, Mar. Micropaleontol., 39, 1-34, https://doi.org/10.1016/S03778398(00)00010-4, 2000.

de Vries, J., Monteiro, F., Wheeler, G., Poulton, A., Godrijan, J., Cerino, F., Malinverno, E., Langer, G., and Brownlee, C.: Haplodiplontic life cycle expands coccolithophore niche, Biogeo- sciences, 18, 1161-1184, https://doi.org/10.5194/bg-18-11612021, 2021.

Dunkley Jones, T. D., Bown, P. R., and Pearson, P. N.: Exceptionally well preserved upper Eocene to lower Oligocene calcareous nannofossils (Prymnesiophyceae) from the Pande Formation (Kilwa Group), Tanzania, J. Syst. Palaeontol., 7, 359-411, https://doi.org/10.1017/S1477201909990010, 2009.

Frada, M., Percopo, I., Young, J., Zingone, A., de Vargas, C., and Probert, I.: First observations of heterococcolithophore-holococcolithophore life cycle combinations in the family Pontosphaeraceae (Calcihaptophycideae, Haptophyta), Mar. Micropaleontol., 71, 20-27, https://doi.org/10.1016/j.marmicro.2009.01.001, 2009.

Frada, M. J., Bendif, E. M., Keuter, S., and Probert, I.: The private life of coccolithophores, Perspect. Phycol., 6, 11-30, https://doi.org/10.1127/pip/2018/0083, 2019.

Franklin, D., Steinke, M., Young, J., Probert, I., and Malin, G.: Dimethylsulphoniopropionate (DMSP), DMSP-lyase activity (DLA) and dimethylsulphide (DMS) in 10 species of coccolithophore, Mar. Ecol.-Prog. Ser., 410, 13-23, https://doi.org/10.3354/meps08596, 2010.

Geisen, M., Billard, C., Broerse, A. T. C., Cros, L., Probert, I., and Young, J. R.: Life-cycle associations involving pairs of holococcolithophorid species: intraspecific variation or cryptic speciation?, Eur. J. Phycol., 37, 531-550, https://doi.org/10.1017/S0967026202003852, 2002.

Genin, A., Lazar, B., and Brenner, S.: Vertical mixing and coral death in the Red Sea following the eruption of Mount Pinatubo, Nature, 377, 507-510, https://doi.org/10.1038/377507a0, 1995.

Godrijan, J., Drapeau, D., and Balch, W. M.: Mixotrophic uptake of organic compounds by coccolithophores, Limnol. Oceanogr., 65, 1410-1421, https://doi.org/10.1002/lno.11396, 2020.

Hagino, K. and Young, J. R.: Biology and Paleontology of Coccolithophores (Haptophytes), in: Marine Protists, edited by: Ohtsuka, S., Suzaki, T., Horiguchi, T., Suzuki, N., and Not, F., Springer, Tokyo, 311-330, https://doi.org/10.1007/978-4-43155130-0_12, 2015.

Houdan, A., Billard, C., Marie, D., Not, F., Sáez, A. G., Young, J. R., and Probert, I.: Holococcolithophoreheterococcolithophore (Haptophyta) life cycles: Flow cytometric analysis of relative ploidy levels, Syst. Biodivers., 1, 453-465, https://doi.org/10.1017/S1477200003001270, 2004.

Jordan, R. W.: Cocccolithophorid communities in the northeast Atlantic, PhD Thesis, University of Surrey, England, 350 pp., 1988.

Jordan, R. W. and Young, J. R.: Proposed changes to the classification system of living coccolithophorids, Int. Nannoplankton. Assoc. Newslett., 12, 15-18, 1990.

Kamptner, E.: Die Coccolithineen der Südwestküste von Istrien, Ann. des Naturhistorischen Museums Wien, 54-149, 1941.

Karatsolis, B.-T., Dimiza, M., and Triantaphyllou, M.: Verification of the Coronosphaera mediterranea - "Zygosphaera hellenica" life-cycle association, J. Nannoplankt. Res., 34, 45-46, 2014.

Keuter, S., Young, J. R., and Frada, M. J.: Life cycle association of the coccolithophore Syracosphaera gaarderae comb. nov. (ex Alveosphaera bimurata): Taxonomy, ecology and evolutionary implications, Mar. Micropaleontol., 148, 58-64, https://doi.org/10.1016/j.marmicro.2019.03.007, 2019.

Kleijne, A.: Holococcolithophorids from the Indian Ocean, Red Sea, Mediterranean Sea and North Atlantic Ocean, 
Mar. Micropaleontol., 17, 1-76, https://doi.org/10.1016/03778398(91)90023-Y, 1991.

Kleijne, A. and Cros, L.: Ten new extant species of the coccolithophore Syracosphaera and a revised classification scheme for the genus, Micropaleontology, 55, 425-462, 2009.

Lecal-Schlauder, J.: Recherches morphologiques et biologiques sur les Coccolithophorides Nord-Africains, Ann. l'Institut Océanographique, Monaco Paris, 26, 255-362, 1951.

Lindell, D. and Post, A. F.: Ultraphytoplankton succession is triggered by deep winter mixing in the Gulf of Aqaba (Eilat), Red Sea, Limnol. Oceanogr., 40, 1130-1141, https://doi.org/10.4319/lo.1995.40.6.1130, 1995.

Lohmann, H.: Die Coccolithophoridae, eine Monographie der Coccolithen bildenden Flagellaten, zugleich ein Beitrag zur Kenntnis des Mittelmeerauftriebs, Arch. Protistenkd., 1, 89-165, 1902.

Mackey, K. R. M., Rivlin, T., Grossman, A. R., Post, A. F., and Paytan, A.: Picophytoplankton responses to changing nutrient and light regimes during a bloom, Mar. Biol., 156, 1531-1546, https://doi.org/10.1007/s00227-009-1185-2, 2009.

Manton, I. and Oates, K.: Fine-structural observations on Papposphaera Tangen from the Southern Hemisphere and on Pappomonas gen. nov. from South Africa and Greenland, Br. Phycol. J., 10, 93-109, https://doi.org/10.1080/00071617500650091, 1975.

Manton, I. and Oates, K.: Nannoplankton from the Galapagos Islands: Two genera of spectacular coccolithophorids (Ophiaster and Calciopappus), with special emphasis on unmineralized periplast components, Philos. T. Roy. Soc. Lond., 300, 435-462, 1983.

McGrane, P. B.: Extant coccolithophores in Irish shelf waters of the northeast Atlantic, PhD thesis, Galway University, 2007.

Medlin, L. K., Sáez, A. G., and Young, J. R.: A molecular clock for coccolithophores and implications for selectivity of phytoplankton extinctions across the K/T boundary, Mar. Micropaleontol., 67, 69-86, https://doi.org/10.1016/j.marmicro.2007.08.007, 2008.

Milliman, J. D.: Production and accumulation of calcium carbonate in the ocean: Budget of a nonsteady state, Global Biogeochem. Cy., 7, 927-957, https://doi.org/10.1029/93GB02524, 1993.

Molfino, B. and McIntyre, A.: Precessional forcing of nutricline dynamics in the equatorial Atlantic, Science, 249, 766-769, https://doi.org/10.1126/science.249.4970.766, 1990.

Norris, R.: Indian Ocean Nannoplankton. II. Holococcolithophorids (Calyptrosphaeraceae, Prymnesiophyceae) with a review of extant genera, J. Phycol., 21, 619-641, https://doi.org/10.1111/j.0022-3646.1985.00619.x 1985.

Okada, H. and Honjo, S.: The distribution of oceanic coccolithophorids in the Pacific, Deep-Sea Res. Oceanogr. Abstr., 20, 355-374, https://doi.org/10.1016/0011-7471(73)90059-4, 1973.

Okada, H. and McIntyre, A.: Seasonal distribution of modern coccolithophores in the western North Atlantic Ocean, Mar. Biol., 54, 319-328, https://doi.org/10.1007/BF00395438, 1979.

Perch-Nielsen, K.: New Tertiary calcareous nannofossils from the South Atlantic, Eclogae Geol. Helv., 73, 1-7, 1980.

Poulton, A. J., Adey, T. R., Balch, W. M., and Holligan, P. M.: Relating coccolithophore calcification rates to phytoplankton community dynamics: Regional differences and implications for carbon export, Deep-Sea Res. Pt. II, 54, 538-557, https://doi.org/10.1016/j.dsr2.2006.12.003, 2007.
Poulton, A. J., Holligan, P. M., Charalampopoulou, A., and Adey, T. R.: Coccolithophore ecology in the tropical and subtropical Atlantic Ocean: New perspectives from the Atlantic meridional transect (AMT) programme, Prog. Oceanogr., 158, 150 170, https://doi.org/10.1016/j.pocean.2017.01.003, 2017.

Quinn, P. S., Cortés, M. Y., and Bollmann, J.: Morphological variation in the deep ocean-dwelling coccolithophore Florisphaera profunda (Haptophyta), Eur. J. Phycol., 40, 123133, https://doi.org/10.1080/09670260400024667, 2005.

Ribera d'Alcalà, M., Conversano, F., Corato, F., Licandro, P., Mangoni, O., Marino, D., Mazzocchi, M. G., Modigh, M., Montresor, M., Nardella, M., Saggiomo, V., Sarno, D., and Zingone, A.: Seasonal patterns in plankton communities in pluriannual time series at a coastal Mediterranean site (Gulf of Naples): An attempt to discern recurrences and trends, Sci. Mar., 68, 65-83, https://doi.org/10.3989/scimar.2004.68s165, 2004.

Šupraha, L., Ljubečić, Z., Mihanović, H., and Henderiks, J.: Coccolithophore life-cycle dynamics in a coastal Mediterranean ecosystem: Seasonality and species-specific patterns, J. Plankton Res., 38, 1178-1193, https://doi.org/10.1093/plankt/fbw061, 2016.

Tangen, K.: Papposphaera lepida, gen. nov., n. sp., a new marine coccolithophorid from Norwegian coastal waters, Nor. J. Bot., 19, 171-178, 1972.

Thomsen, H. A. and Egge, J. K.: Papposphaera heldalii sp. nov. (Haptophyta, Papposphaeraceae) from Svalbard, Acta Protozool., 55, 27-32, https://doi.org/10.4467/16890027AP.16.004.4045, 2016.

Thomsen, H. A. and Østergaard, J.: Coccolithophorids in Polar Waters: Pappomonas spp. Revisited, Acta Protozool., 53, 235-256, https://doi.org/10.4467/16890027AP.14.022.1997, 2014.

Thomsen, H. A. and Østergaard, J. B.: Coccolithophorids in Polar Waters: Trigonaspis spp. Revisited, Acta Protozool., 54, 419436, 2015.

Thomsen, H. A. and Østergaard, J. B.: Papposphaera iugifera nov. sp. from West Greenland, Svalbard, and the Baltic Sea, Rev. Micropaléontol., 59, 71-79, https://doi.org/10.1016/j.revmic.2015.09.001, 2016.

Thomsen, H. A., Buck, K. R., Coale, S. L., Garrison, D. L., and Gowing, M. M.: Nanoplanktonic coccolithophorids (Prymnesiophyceae, Haptophyceae) from the Weddell Sea, Antarctica, Nord. J. Bot., 8, 419-436, 1988.

Thomsen, H. A., Østergaard, J., and Hansen, L. E: Heteromorphic life histories in Arctic coccolithophorids (Prymnesiophyceae), J. Phycol., 27, 634-642, https://doi.org/10.1111/j.00223646.1991.00634.x, 1991.

Thomsen, H. A., Østergaard, J. B., and Heldal, M.: Coccolithophorids in Polar Waters: Wigwamma spp. Revisited, Acta Protozool., 52, 237-256, https://doi.org/10.4467/16890027AP.13.021.1118, 2013.

Thomsen, H. A., Østergaard, J. B., and Cros, L.: Ventimolina stellata gen. et sp. nov. (Haptophyta, Papposphaeraceae) from warm water regions, Acta Protozool., 54, 275-281, https://doi.org/10.4467/16890027AP.15.022.3536, 2015.

Thomsen, H. A., Østergaard, J. B., and Heldal, M.: Coccolithophores in Polar Waters: Papposphaera sagittifera HET and HOL Revisited, Acta Protozool., 55, 33-50, https://doi.org/10.4467/16890027AP.16.005.4046, 2016a. 
Thomsen, H. A., Heldal, M., and Østergaard, J. B.: Coccolithophores in Polar Waters: Papposphaera arctica HET and HOL revisited, Micropaleontology, 61, 419-427, 2016b.

Thomsen, H. A., Heldal, M., and Østergaard, J. B.: Coccolithophores in Polar Waters: Papposphaera sarion HET and HOL revisited, Micropaleontology, 61, 429-438, 2016c.

Thomsen, H. A., Cros, L., Malinverno, E., Østergaard, J. B., Cortés, M. Y., Geisen, M., and Young, J. R.: Formonsella pyramidosa (Haptophyta, Papposphaeraceae): a new weakly calcified coccolithophore genus from warm-water regions, J. Micropalaeontol., 35, 125-132, https://doi.org/10.1144/jmpaleo2015-013, $2016 \mathrm{~d}$.

Triantaphyllou, M. V., Karatsolis, B.-T., Dimiza, M. D., Malinverno, E., Cerino, F., Psarra, S., Jordan, R. W., and Young, J. R.: Coccolithophore combination coccospheres from the NE Mediterranean Sea: new evidence and taxonomic revisions, Micropaleontology, 61, 457-472, 2016.

Turland, N. J., Wiersema, J. H., Barrie, F. R., Greuter, W., Hawksworth, D. L., Herendeen, P. S., Knapp, S., Kusber, W.-H., Li, D.-Z., Marhold, K., May, T. W., McNeill, J., Monro, A. M., Prado, J., Price, M. J., and Smith, G. F. (Eds.): International Code of Nomenclature for algae, fungi, and plants (Shenzhen Code) adopted by the Nineteenth International Botanical Congress Shenzhen, China, July 2017, Regnum Vegetabile 159, Koeltz Botanical Books, Glashütten, https://doi.org/10.12705/Code.2018, 2018.

Winter, A., Reiss, Z., and Luz, B.: Distribution of living coccolithophore assemblages in the Gulf of Elat ('Aqaba), Mar. Micropaleontol., 4, 197-223, https://doi.org/10.1016/03778398(79)90017-3, 1979.

Yang, T.-N., Wei, K.-Y., and Gong, G. C.: Distribution of coccolithophorids and coccoliths in surface ocean off north-eastern Taiwan, Bot. Bull. Acad. Sin. Taipei, 42, 287-302, 2001.

Young, J. R., Bergen, J. A., Bown, P. R., Burnett, J. A., Fiorentino, A., Jordan, R. W., Kleijne, A., van Niel, B. E., Romein, A. J. T., and Von Salis, K.: Guidelines for coccolith and calcareous nannofossil terminology, Palaeontology, 40, 875-912, 1997.

Young, J. R., Davis, S. A., Bown, P. R., and Mann, S.: Coccolith ultrastructure and biomineralisation, J. Struct. Biol., 126, 195215, https://doi.org/10.1006/JSBI.1999.4132, 1999.
Young, J. R., Geisen, M., Cros, L., Kleijne, A, Sprengel, C., Probert, I., and Østergaard, J.: A guide to extant coccolithophore taxonomy, Nannoplankt. Res., Special Issue 1, 2003.

Young, J. R., Geisen, M., and Probert, I.: A review of selected aspects of coccolithophore biology with implications for paleobiodiversity estimation, Micropaleontology, 51, 267-288, 2005.

Young, J. R., Andruleit, H., and Probert, I.: Coccolith function and morphogenesis: insights from appendage-bearing coccolithophores of the family Syracosphaeraceae (Haptophyta), J. Phycol., 45, 213-226, https://doi.org/10.1111/j.15298817.2008.00643.x, 2009.

Young, J. R., Henriksen, K., and Probert, I.: Structure and morphogenesis of the coccoliths of the CODENET species, edited by: Thierstein, H. R. and Young, J. R., Coccolithophores - From molecular processes to global impact, Springer, Berlin, 191-216, 2004.

Young, J. R., Bown, P. R., Cros, L., Hagino, K., and Jordan, R. W.: Syracosphaera azureaplaneta sp. nov. and revision of Syracosphaera corolla Lecal, 1966 Hagino, J. Nannoplankt. Res., 38, $1-6,2018$.

Young, J. R., Bown, P. R., and Lees, J. A.: Nannotax3 Website, International Nannoplankton Association, available at: https:// www.mikrotax.org/Nannotax3, last access: 23 July 2021.

Zarubin, M., Lindemann, Y., and Genin, A.: The dispersionconfinement mechanism: Phytoplankton dynamics and the spring bloom in a deeply-mixing subtropical sea, Prog. Oceanogr., 155, 13-27, https://doi.org/10.1016/j.pocean.2017.05.005, 2017.

Zingone, A., Dubroca, L., Iudicone, D., Margiotta, F., Corato, F., Ribera d'Alcalà, M., Saggiomo, V., and Sarno, D.: Coastal phytoplankton do not rest in winter, Estuarie. Coast., 33, 342-361, https://doi.org/10.1007/s12237-009-9157-9, 2010.

Zingone, A., D’Alelio, D., Mazzocchi, M. G., Montresor, M., Sarno, D., and LTER-MC Team: Time series and beyond: multifaceted plankton research at a marine Mediterranean LTER site, Nat. Conserv., 34, 273, https://doi.org/10.3897/natureconservation.34.30789, 2019.

Ziveri, P., de Bernardi, B., Baumann, K.-H., Stoll, H. M., and Mortyn, P. G.: Sinking of coccolith carbonate and potential contribution to organic carbon ballasting in the deep ocean, Deep-Sea Res. Pt. II, 54, 659-675, https://doi.org/10.1016/j.dsr2.2007.01.006, 2007. 